\title{
Are dietary strategies to mitigate enteric methane emission equally effective across dairy cattle, beef cattle, and sheep?
}

\author{
Sanne van Gastelen, ${ }^{1,2 *}$ Jan Dijkstra, ${ }^{1}$ and André Bannink ${ }^{2}$ \\ ${ }^{1}$ Animal Nutrition Group, Wageningen University \& Research, PO Box 338, 6700 AH, Wageningen, the Netherlands \\ ${ }^{2}$ Wageningen Livestock Research, Wageningen University \& Research, PO Box 338, $6700 \mathrm{AH}$, Wageningen, the Netherlands
}

\section{ABSTRACT}

The digestive physiology of ruminants is sufficiently different (e.g., with respect to mean retention time of digesta, digestibility of the feed offered, digestion, and fermentation characteristics) that caution is needed before extrapolating results from one type of ruminant to another. The objectives of the present study were (1) to provide an overview of some essential differences in rumen physiology between dairy cattle, beef cattle, and sheep that are related to methane $\left(\mathrm{CH}_{4}\right)$ emission; and (2) to evaluate whether dietary strategies to mitigate $\mathrm{CH}_{4}$ emission with various modes of action are equally effective in dairy cattle, beef cattle, and sheep. A literature search was performed using Web of Science and Scopus, and 94 studies were selected from the literature. Per study, the effect size of the dietary strategies was expressed as a proportion (\%) of the control level of $\mathrm{CH}_{4}$ emission, as this enabled a comparison across ruminant types. Evaluation of the literature indicated that the effectiveness of forage-related $\mathrm{CH}_{4}$ mitigation strategies, including feeding more highly digestible grass (herbage or silage) or replacing different forage types with corn silage, differs across ruminant types. These strategies are most effective for dairy cattle, are effective for beef cattle to a certain extent, but seem to have minor or no effects in sheep. In general, the effectiveness of other dietary mitigation strategies, including increased concentrate feeding and feed additives (e.g., nitrate), appeared to be similar for dairy cattle, beef cattle, and sheep. We concluded that if the mode of action of a dietary $\mathrm{CH}_{4}$ mitigation strategy is related to ruminant-specific factors, such as feed intake or rumen physiology, the effectiveness of the strategy differs across ruminant types, whereas if the mode of action is associated with methanogenesis-related fermentation pathways, the strategy is effective across ruminant types. Hence, caution is needed when translating ef-

Received October 2, 2018

Accepted March 12, 2019.

*Corresponding author: sanne.vangastelen@wur.nl fectiveness of dietary $\mathrm{CH}_{4}$ mitigation strategies across different ruminant types or production systems.

Key words: methane, dietary strategy, ruminant, in vivo measurement

\section{INTRODUCTION}

Enteric fermentation enables ruminants to effectively turn human inedible biomass, such as coarse plant material, into high quality human-consumable protein in the form of milk and meat (Gerber et al., 2015), but this process also coincides with methane $\left(\mathrm{CH}_{4}\right)$ production by methanogenic Archaea (McAllister and Newbold, 2008). The amount of feed consumed and the composition of the diet have major impacts on enteric $\mathrm{CH}_{4}$ production. Hence, several dietary strategies (e.g., supplementing lipids or specific additives, improving forage quality, feeding different forage types) to mitigate enteric $\mathrm{CH}_{4}$ have been studied (e.g., Martin et al., 2010; Hristov et al., 2013a). Although all types of ruminant animals (e.g., cattle, goats, sheep) might have similar $\mathrm{CH}_{4}$-forming pathways in the rumen, they differ considerably in their level of feed intake, rumen morphology, and rumen physiology. Consequently, the effectiveness of dietary strategies to mitigate $\mathrm{CH}_{4}$ emission might also differ across different types of ruminants. The number of studies directly comparing rumen physiology across different types of ruminants is limited. Additionally, studies involving the evaluation of dietary $\mathrm{CH}_{4}$ mitigation strategies in multiple ruminant types are lacking. Hence, in the present paper, we aimed (1) to provide a brief overview of differences in rumen physiology between dairy cattle, beef cattle, and sheep that are related to $\mathrm{CH}_{4}$ emission; and (2) to evaluate whether dietary strategies to mitigate $\mathrm{CH}_{4}$ emission with various modes of action are equally effective in dairy cattle, beef cattle, and sheep.

\section{MATERIALS AND METHODS}

To evaluate whether $\mathrm{CH}_{4}$-mitigating dietary strategies with various modes of action are equally effective in dairy cattle, beef cattle, and sheep, we first identi- 
fied key areas of differences directly related to rumen physiology and rumen functioning, including feed intake level, ruminal degradation, passage rate and mean retention time (MRT), rumen fermentation parameters, rumen microbial community, total-tract digestibility, and ruminant genotype.

Second, we performed a literature search to evaluate the effectiveness of $\mathrm{CH}_{4}$ mitigation strategies, using Web of Science (Thomson Reuters Science, New York, NY) and Scopus (Elsevier, Amsterdam, the Netherlands), with a focus on forage quality, forage type and forage replacement, forage to concentrate ratio, and feed additives that have been tested in multiple ruminant types. These dietary strategies are recommended $\mathrm{CH}_{4^{-}}$ mitigation practices according to a review by Hristov et al. (2013a,b). Scientific papers were selected if they met all the following criteria: (1) an in vivo experiment was conducted; (2) the $\mathrm{CH}_{4}$ emissions were measured directly (i.e., not estimated); (3) the composition of the basal diet was described; (4) the results were available on DMI, and on $\mathrm{CH}_{4}$ production $(\mathrm{g} / \mathrm{d})$ or $\mathrm{CH}_{4}$ yield $[\mathrm{g} / \mathrm{kg}$ of DMI or \% of gross energy intake (GEI)]; and (5) a statistical analysis was performed. Although preferred, the studies did not have to involve the testing of dietary strategies in multiple types of ruminants. A total of 94 studies were selected.

The effect size of the dietary strategies was determined for each individual study, expressed as a proportion (\%) of the $\mathrm{CH}_{4}$ emission for the control treatment and based on the reported treatment means [percentage increase or decrease relative to the value established with the "baseline" or control treatment (e.g., the percentage change in $\mathrm{CH}_{4}$ emission with supplementation of the highest nitrate dose compared with no supplementation of nitrate)]. The level of DMI and $\mathrm{CH}_{4}$ emission varies greatly across studies and from one type of ruminant to another. Hence, comparing the size of the effect in absolute terms (e.g., $\mathrm{kg} / \mathrm{d}$ for DMI and $\mathrm{g} / \mathrm{d}$ or $\mathrm{g} / \mathrm{kg}$ of DMI for $\mathrm{CH}_{4}$ ) is difficult. Expressing effect size as a percentage therefore served as a more feasible alternative. The size of effect was calculated including all studies, irrespective of whether significant differences were reported by the respected studies. If fewer than 3 studies per dietary strategy $\times$ ruminant type were available, however, the studies were only included in the tables to provide a complete overview but not used to calculate effect sizes or used to formulate conclusions.

\section{RESULTS AND DISCUSSION}

\section{Comparative Rumen Physiology}

The total daily $\mathrm{CH}_{4}$ production of a sheep is typically only $12 \%$ of that of a dairy cow (Ulyatt et al., 2002).
However, results are less consistently reported for $\mathrm{CH}_{4}$ expressed per unit of feed intake $[\mathrm{g} / \mathrm{kg}$ of DMI or as a percent of GEI; e.g., Blaxter and Wainman, 1961; Swainson et al., 2008]. Although studies comparing rumen digestive physiology across different ruminant types are limited, some have argued that differences in fractional passage rate, rumen fermentation conditions, and apparent digestibility across ruminant types caused differences in $\mathrm{CH}_{4}$ yield (both as $\mathrm{g} / \mathrm{kg}$ of DMI and as \% of GEI; Aerts et al., 1984; Pearson et al., 2006), whereas others have argued that differences in microbial populations and site of digestion were responsible for differences in $\mathrm{CH}_{4}$ yield across ruminant types (e.g., Swainson et al., 2008).

\section{Feed Intake Level}

On a daily basis, in grams per day, it is obvious that both dairy and beef cattle have a higher DMI capacity and a higher realized DMI than sheep because of their larger body size, greater nutritional requirements, and larger rumen capacity. Soto-Navarro et al. (2014) demonstrated that beef cattle consumed more feed than sheep when DMI was expressed per unit of metabolic BW. However, as forage quality decreased (lower OM digestibility, OMD), this difference in DMI relative to metabolic BW became smaller. Colucci et al. (1989) observed a depression in digestibility of different feed fractions with increasing feed intake for dairy cattle and sheep. This is most likely the result of a shorter MRT in the rumen, increased fractional passage rate, and decreased ruminal fermentation for both dairy cattle and sheep as feed intake increases. Notably, the depression of digestibility appeared to be greater for cattle than for sheep, most likely because cattle appear to have a lower digestive capacity than sheep (Colucci et al., 1989).

\section{Ruminal Degradation}

Siddons and Paradine (1983) demonstrated that in situ rumen degradation of several feedstuffs was lower for beef steers than for sheep, irrespective of incubation time. Lower fractional degradation rates in beef and dairy cattle than in sheep have been observed in other studies as well (e.g., Poppi et al., 1981; Udén and Van Soest, 1984; Šebek and Everts, 1999). These observed differences between cattle and sheep in in situ fractional degradation rates may have several causes, such as differences in the rations offered, differences in in situ techniques, and differences in the amount of nutrient recycling in the rumen (Lindberg, 1985; Nocek, 1988). The consistent findings reported across the literature indicate that differences in rumen fractional degrada- 
tion kinetics between cattle (beef and dairy) and sheep are not caused by methodological differences alone, but are also due to between-ruminant differences. It has been suggested that differences in feed fractional degradation rates in the rumen might be caused by lower rumen ammonia levels in dairy and beef cattle compared with sheep (Poppi et al., 1981; Siddons and Paradine, 1983). Other factors that may play a role are body size and, subsequently, rumen size and rumen fluid volumes (Lechner-Doll et al., 1991), as well as feed intake relative to rumen volume, passage rate, and ruminal $\mathrm{pH}$.

\section{Passage Rate and MRT}

The passage rate of digesta through the digestive tract, particularly through the rumen, has been linked to $\mathrm{CH}_{4}$ emissions (Swainson et al., 2008). Okine et al. (1989) reported significant inverse relationships between fractional passage rate constants of both ruminal fluid and particulate matter and $\mathrm{CH}_{4}$ production in beef steers. Low $\mathrm{CH}_{4}$ yield $(\mathrm{g} / \mathrm{kg}$ of DMI) of sheep was associated with shorter MRT of liquid and of particulate digesta (Goopy et al., 2014). The association between $\mathrm{CH}_{4}$ emissions and both fractional passage rate and MRT seems to apply to beef cattle and sheep, and most likely to dairy cattle as well. Therefore, it is important to know whether there are differences across ruminant types in terms of fractional passage rate or MRT, as this may affect the $\mathrm{CH}_{4}$ mitigation potential of a dietary strategy.

Lechner-Doll et al. (1991) compared retention times of fluid and small particles in the rumen of zebu cattle and 2 breeds of indigenous sheep. The MRT of fluid in the rumen was similar for both ruminant types (approximately $10 \mathrm{~h}$ ), whereas the labeled particles were retained substantially longer for cattle $(28 \mathrm{~h})$ than for sheep $(20 \mathrm{~h})$. This was consistent with the findings of Reid et al. (1990), Prigge et al. (1984), and Colucci et al. (1990). These results imply that particles are more selectively retained in the rumen of cattle compared with sheep, and that this selective retention is not affected by variation in MRT arising from changes in feed intake level or feed quality (e.g., Grovum and Williams, 1977; Lindberg, 1988).

\section{Rumen Fermentation Parameters}

Rumen fermentation characteristics may or may not differ between different types of ruminants, depending on the type of diet fed and the amount of feed consumed relative to rumen volume. When sheep and beef steers were fed similar diets at maintenance level, Siddons and Paradine (1983) reported a higher total
VFA concentration and molar proportion of propionate in beef steers than in sheep, whereas the molar proportion of acetate was lower. However, Norton et al. (1994) reported a higher molar proportion of butyric acid and lower proportion of acetic acid in beef steers than in sheep for both a molasses diet and a sorghum grain diet, but a lower proportion of propionic acid in beef steers than in sheep was observed only on a molasses diet and not on a sorghum grain diet. Soto-Navarro et al. (2014) demonstrated that ruminal $\mathrm{pH}$ was influenced by a ruminant $x$ forage quality interaction. Ruminal $\mathrm{pH}$ was higher for sheep than for beef steers when alfalfa hay was fed but did not differ when grass hay or lovegrass hay was fed.

\section{Rumen Microbial Community}

Henderson et al. (2015) determined the effect of multiple factors on rumen microbial community composition across a wide geographical range. The differences in composition of microbial communities were predominantly attributed to diet, but an effect of host was also found. Microbial communities could clearly be discriminated by host (i.e., bovines, including dairy and beef cattle, vs. caprids, including sheep), with bacteria, rather than Archaea or protozoa, being the main drivers behind the observed differences. Further, Jeyanathan et al. (2011) reported similar archaeal communities in the rumen of nonlactating dairy cattle and sheep, suggesting a common core of ruminal methanogen species in ruminants. This suggests that the main players in the $\mathrm{CH}_{4}$ production pathway are similar across ruminant types, indicating a similar effectiveness if a dietary strategy targeted the methanogens directly.

\section{Total-Tract Digestibility}

Hindgut fermentation contributes to digestion in the total gastrointestinal tract of ruminants. However, enteric fermentation, and consequently $\mathrm{CH}_{4}$ production, occurs predominantly within the rumen $(\sim 87 \%)$ and to a small extent in the large intestines $(\sim 13 \%$; Murray et al., 1976). In addition, $\mathrm{CH}_{4}$ production per unit of fermented nutrients in the hindgut is generally lower compared with $\mathrm{CH}_{4}$ production per unit of fermented nutrients in the rumen. This is mainly because hindgut fermentation differs from ruminal fermentation (due to absence of active protozoa; Fievez et al., 1999). Therefore, discussion in this section has been limited specifically to digestion within the rumen. Greater digestibility values for $\mathrm{OM}$ and fiber have been reported for dairy and beef cattle than for sheep (e.g., Blaxter et al., 1966; Leaver et al., 1969; McDonald et al., 2002; Pearson et al., 2006) and the difference in digestive 


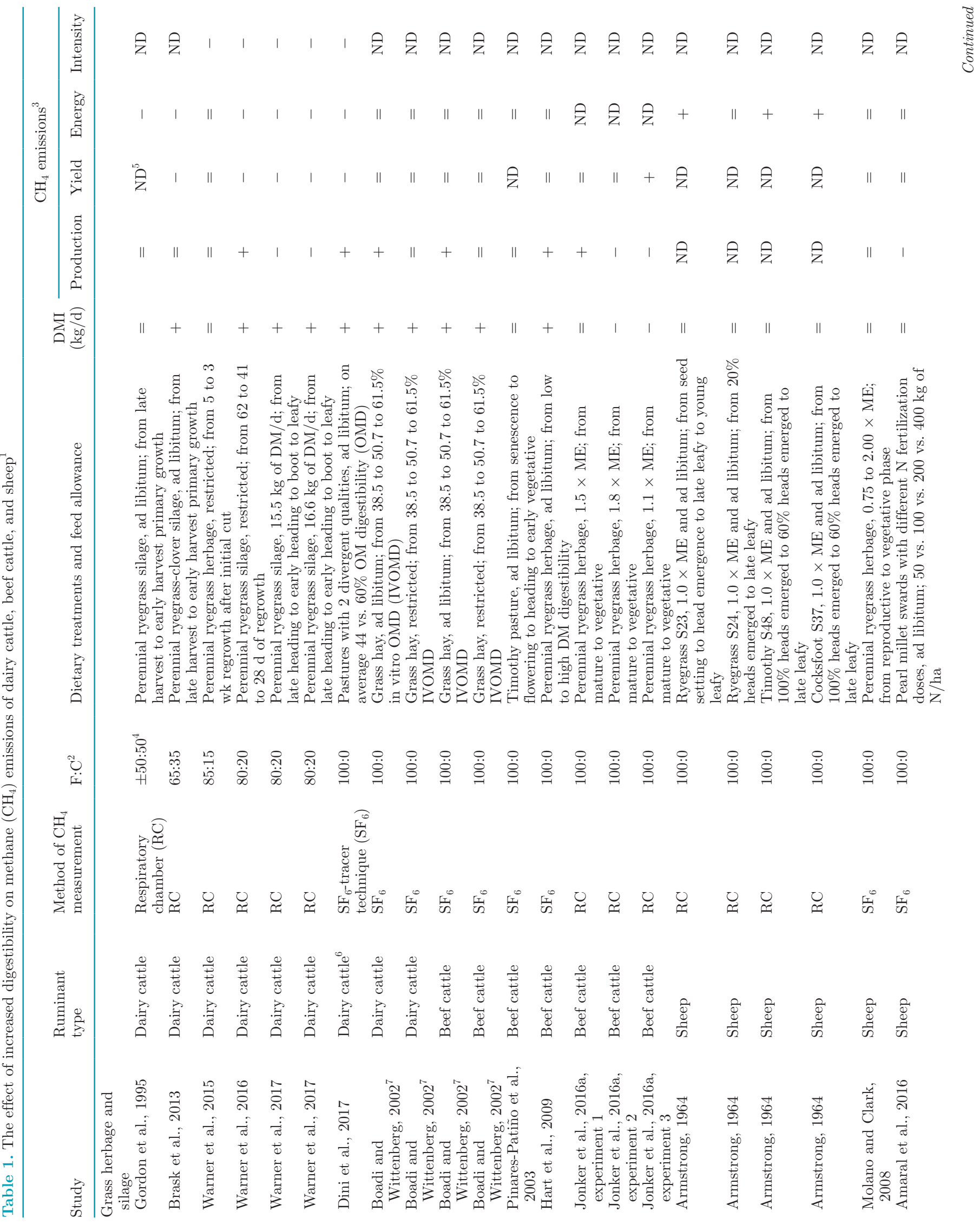


METHANE MITIGATION ACROSS RUMINANT TYPES

capacity appears to become larger as roughage quality decreases (Rees and Little, 1980; Aerts et al., 1984; Prigge et al., 1984; Soto-Navarro et al., 2014). This suggests that when fed a low-quality roughage, dairy and beef cattle appear to have a greater capacity to digest nutrients, in particular fiber and OM compared with sheep. According to Poppi et al. (1980) and Aerts et al. (1984), this may result from ruminal MRT. Sheep, on the other hand, appear to have a greater capacity to digest proteins. Alexander et al. (1962), Aerts et al. (1984), and Südekum et al. (1995) reported that sheep had a greater ability to digest CP than dairy and beef cattle, especially when low-protein forages were fed.

\section{Ruminant Genotype}

Overall, literature findings indicate that the digestive physiology of ruminants is sufficiently different to recommend caution in the extrapolation of the perceived efficacy of $\mathrm{CH}_{4}$-mitigating dietary strategies from one ruminant type to another. It should be noted that a significant proportion of the literature findings in the current overview were reported two or more decades ago. Developments in management and breeding of ruminant animals in the past decades may have affected elements of digestive physiology and the differences across ruminant types. Potts et al. (2017) reported a decline in feed digestibility in dairy cattle between 1970 and 2014, mainly caused by an increased passage rate of feed through the digestive tract. No such developments in intake and digestibility in time are known for sheep, although we expect that such developments have been far more pronounced in cattle than in sheep. We therefore suggest that the observed differences between dairy cattle, beef cattle, and sheep in studies from the 1980s or earlier might not be presently valid due to the development of ruminants and ruminant production systems since that time (e.g., breeding and management factors). Unfortunately, comparative studies from recent years are lacking, and confirming these previous findings proves challenging. That being said, it is important to note that studies describing dietary $\mathrm{CH}_{4}$ mitigation strategies are predominantly from the last 2 decades. Hence, caution should be taken when using results from comparative physiology studies conducted before 1980s to explain differences observed across ruminant types in the effectiveness of dietary $\mathrm{CH}_{4}$ mitigation strategies.

\section{Comparative Effects of Dietary Strategies on Methanogenesis}

Tables 1 to 6 summarize the studies used to determine the effect of several $\mathrm{CH}_{4}$-mitigating dietary strate- 


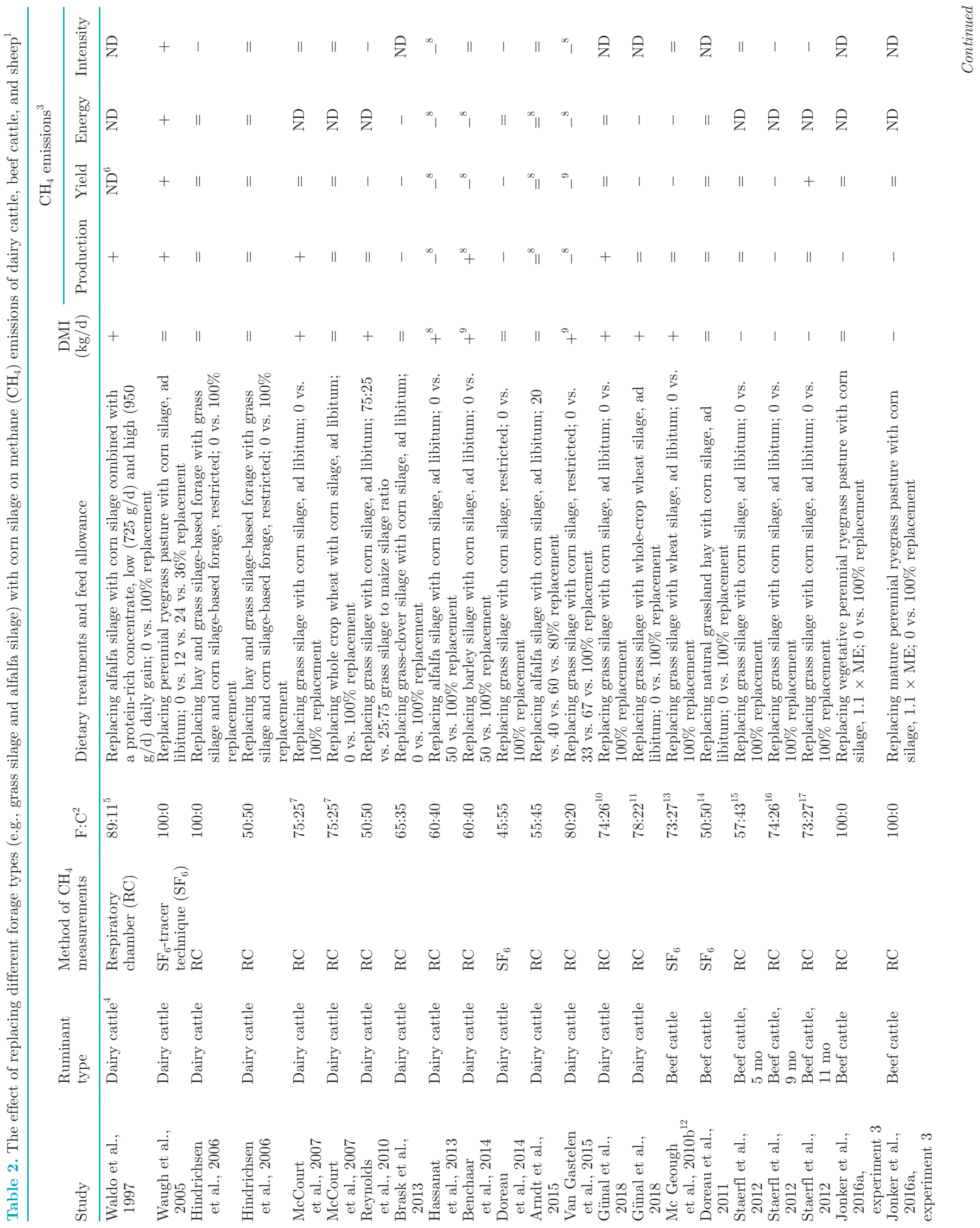


METHANE MITIGATION ACROSS RUMINANT TYPES

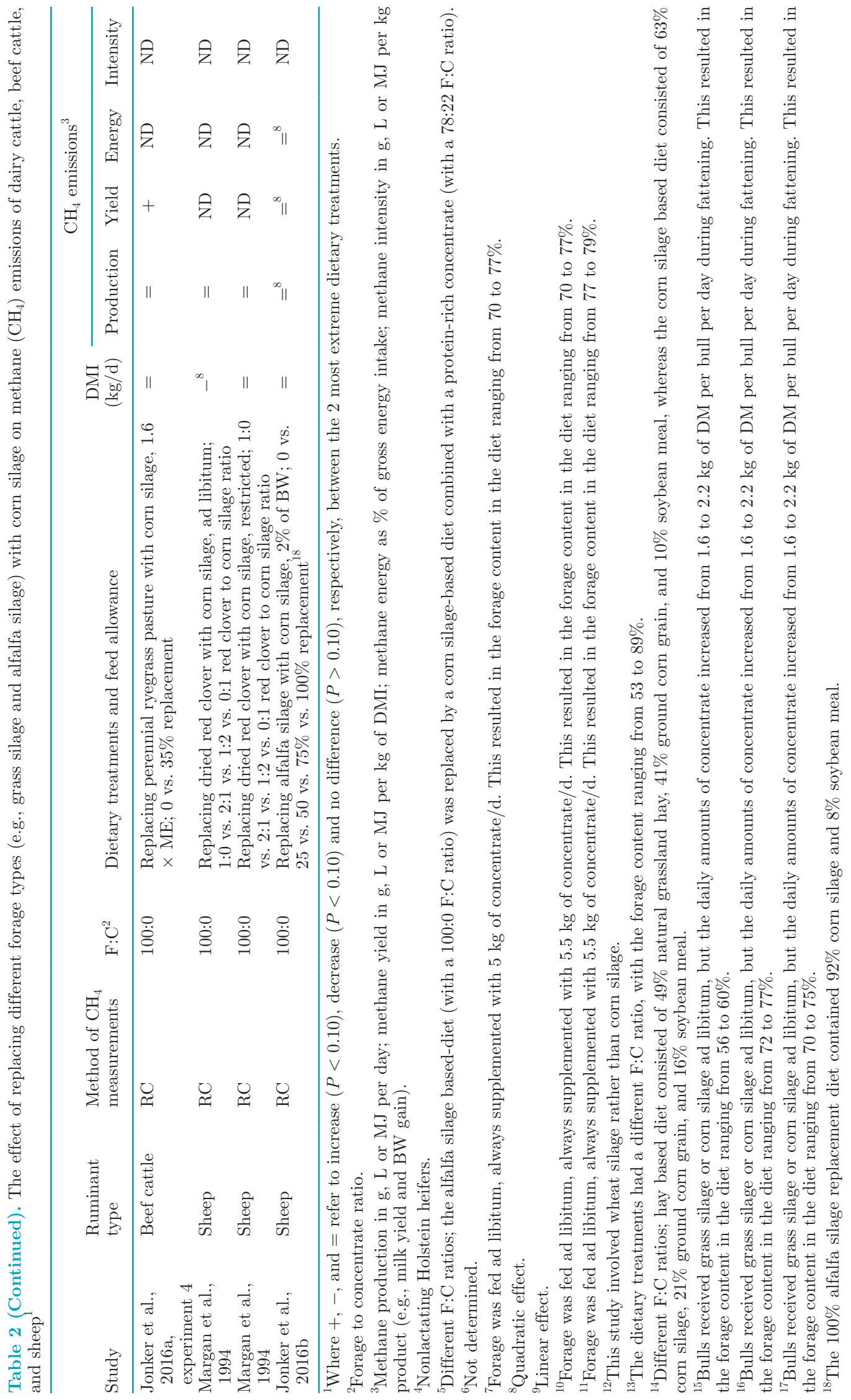

Journal of Dairy Science Vol. 102 No. 7, 2019 


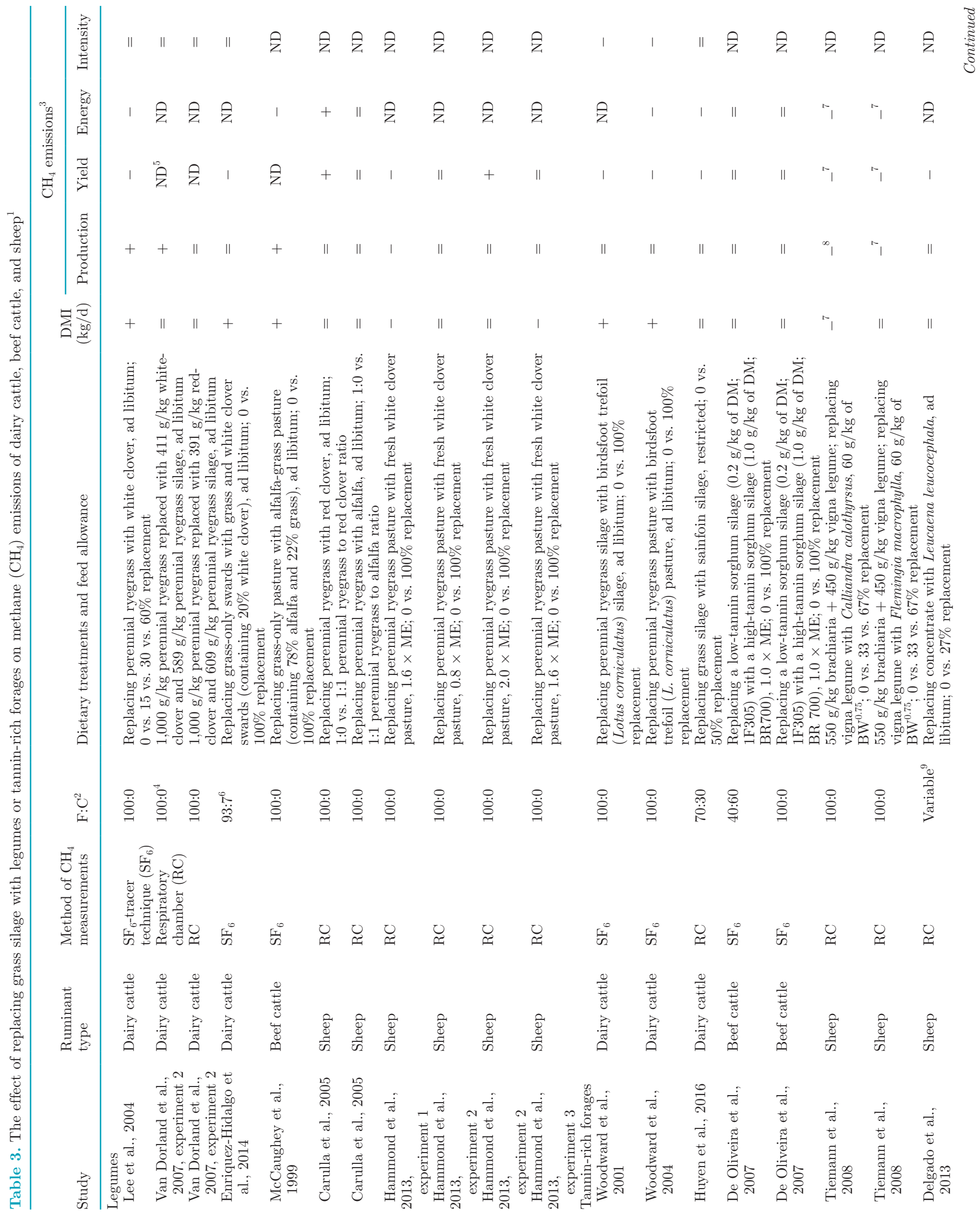




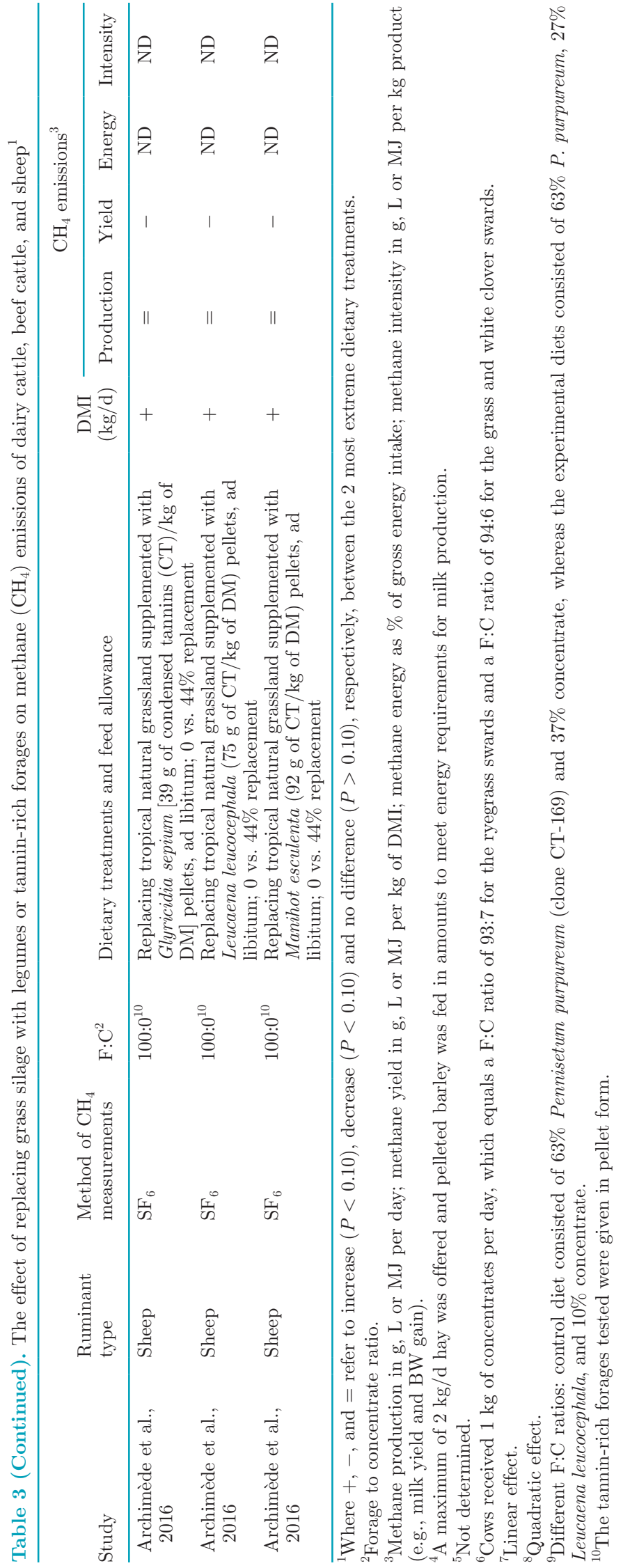

gies on the response variables DMI and $\mathrm{CH}_{4}$ emission expressed in multiple units (i.e., production: L/d per animal or $\mathrm{g} / \mathrm{d}$ per animal; yield: $\mathrm{L} / \mathrm{kg}$ of $\mathrm{DMI}, \mathrm{g} / \mathrm{kg}$ of DMI, or \% of GEI; intensity: $\mathrm{g} / \mathrm{kg}$ of product, with product being milk yield for dairy cattle and ADG for beef cattle and sheep). The symbols used in the tables (i.e.,,-+ , and $=$ ) illustrate whether the response variables were affected; that is, decreased $(P \leq$ $0.10)$, increased $(P \leq 0.10)$, or unaffected $(P>0.10)$, respectively. If more than 2 dietary treatments were applied in a study, the effect on the response variables was rated for the extremes of the treatments of interest (e.g., a diet of lowest digestibility vs. a diet of highest digestibility). If reported, we indicated whether a linear or quadratic effect was found in the respective studies.

\section{Forage Quality}

Table 1 summarizes the studies that investigated the effect of forage digestibility (grass herbage, grass silage, and corn silage) on $\mathrm{CH}_{4}$ emission from dairy cattle, beef cattle, and sheep. Improved digestibility, as reflected by OMD, of grass herbage or grass silage (on average $25 \%$ ) for dairy cattle increased DMI (on average $14 \%$ ) and $\mathrm{CH}_{4}$ production $(\mathrm{g} / \mathrm{d}$; on average $8 \%$ ), whereas $\mathrm{CH}_{4}$ yield ( $\mathrm{g} / \mathrm{kg}$ of DMI or as \% of GEI) and, if available, $\mathrm{CH}_{4}$ intensity ( $\mathrm{g} / \mathrm{kg}$ of milk) decreased 10 and $19 \%$, respectively, on average. For beef cattle, DMI and $\mathrm{CH}_{4}$ production also increased (on average, 10 and $7 \%$, respectively), but $\mathrm{CH}_{4}$ yield (both in $\mathrm{g} / \mathrm{kg}$ of DMI and as \% of GEI) was unaffected with improved OMD (average 33\% OMD improvement). For sheep, improved OMD (on average 17\%) did not affect DMI but increased $\mathrm{CH}_{4}$ yield (\% of GEI) $7 \%$. The number of studies (3) on effect of increased digestibility of other forages was too small to allow quantitative evaluation. Upon an increase in digestibility of corn silage, $\mathrm{CH}_{4}$ emissions were unchanged or increased for both dairy cattle and beef cattle; no data were available for sheep.

These results indicate that the effect of increased grass (herbage or silage) digestibility on $\mathrm{CH}_{4}$ mitigation differs between ruminant types. This strategy seems to be the most effective for dairy cattle, whereas it is not effective for beef cattle, and has no or opposite effects in sheep. Feed allowance in all studies (dairy cattle, beef cattle, and sheep) ranged from restricted (based on free access feed intake for dairy cattle or on ME requirements for beef and sheep) to ad libitum. However, in all beef cattle and sheep studies, no concentrate was fed ( $\mathrm{F}: \mathrm{C}$ ratio of 100:0), whereas in 5 out of 7 dairy cattle studies, concentrate was fed. This difference in $\mathrm{F}$ : $\mathrm{C}$ ratio between studies on dairy cattle and those on beef cattle or sheep might explain part of the difference found across these ruminant types in 


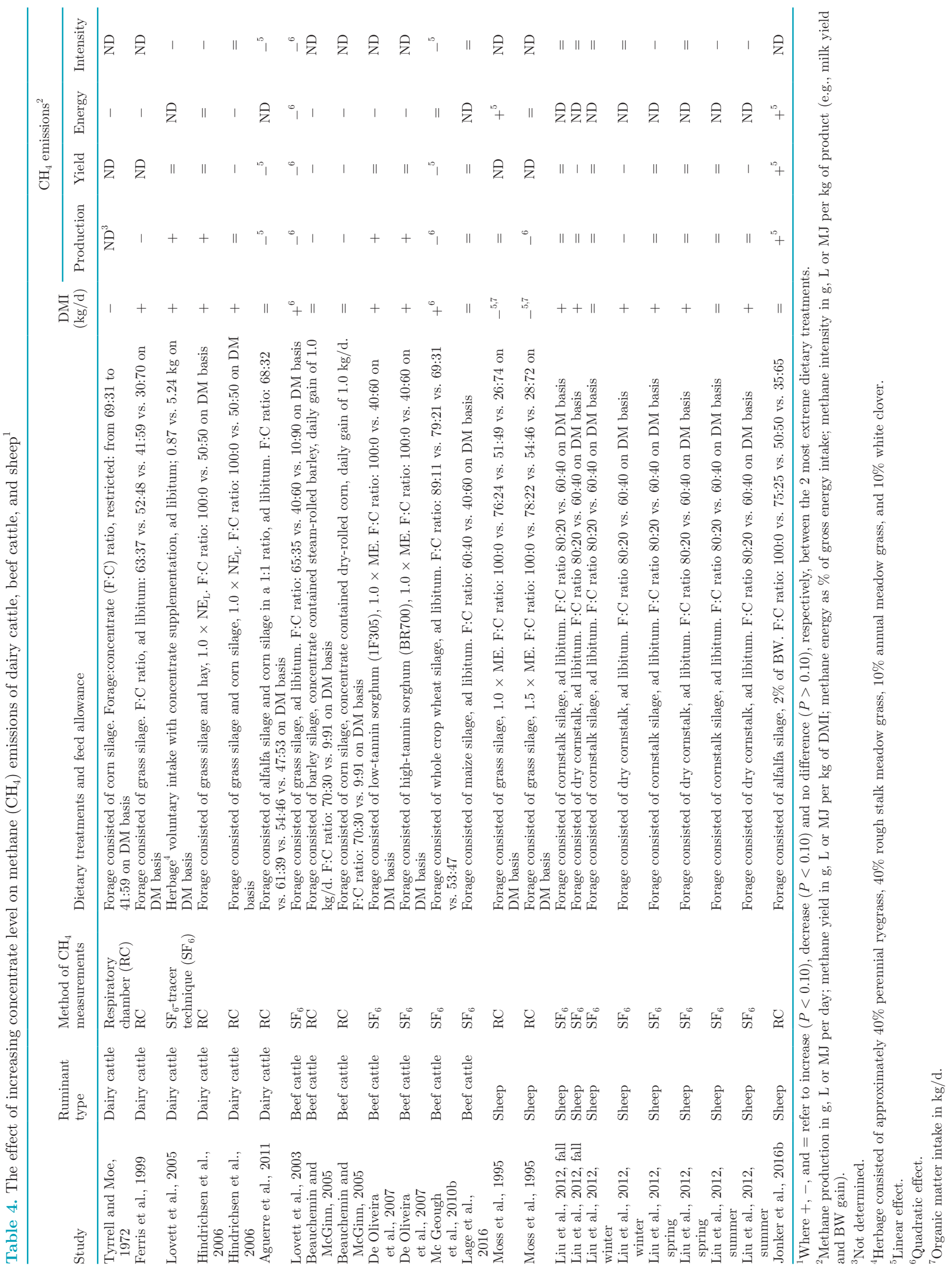


METHANE MITIGATION ACROSS RUMINANT TYPES

6119

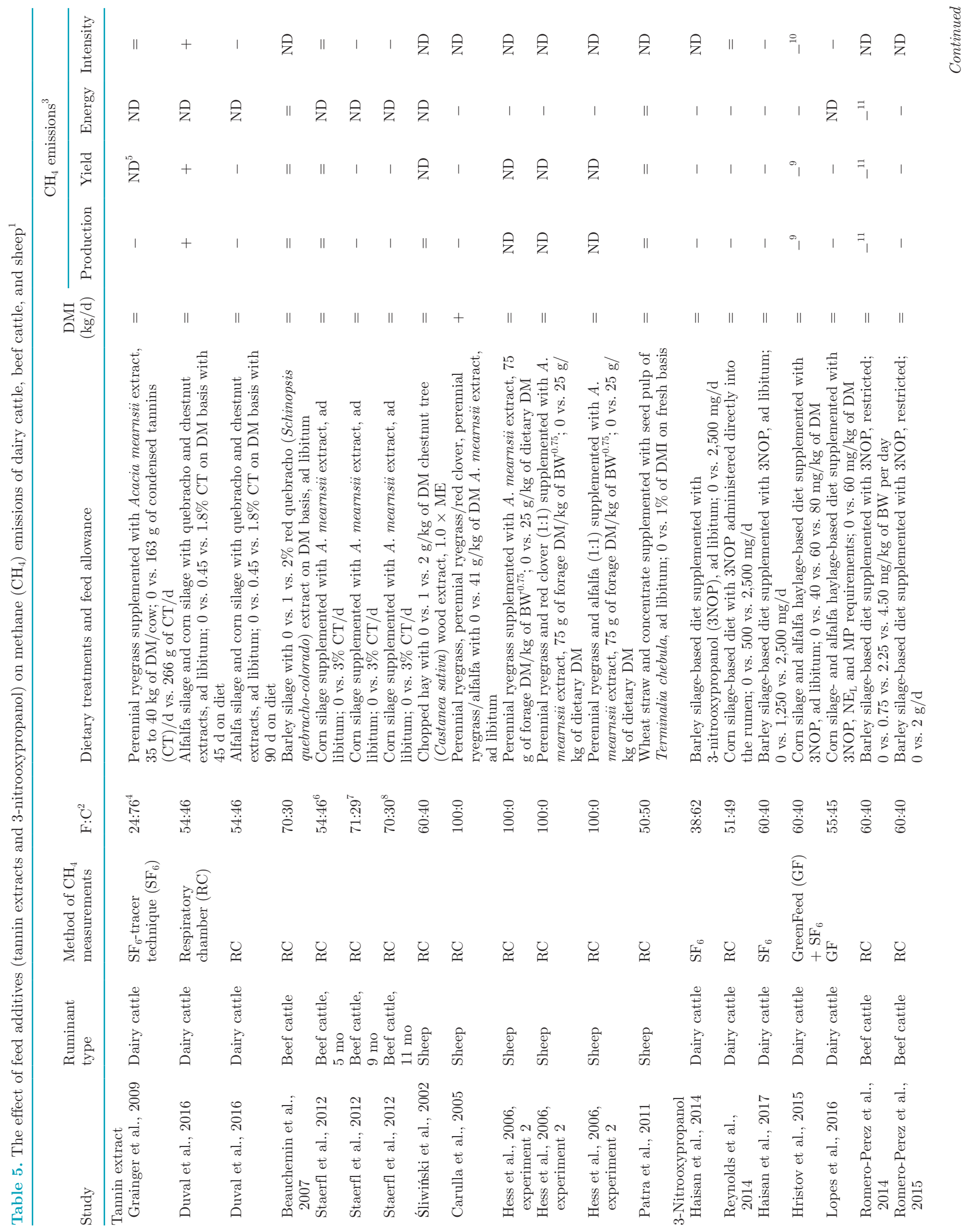


VAN GASTELEN ET AL.

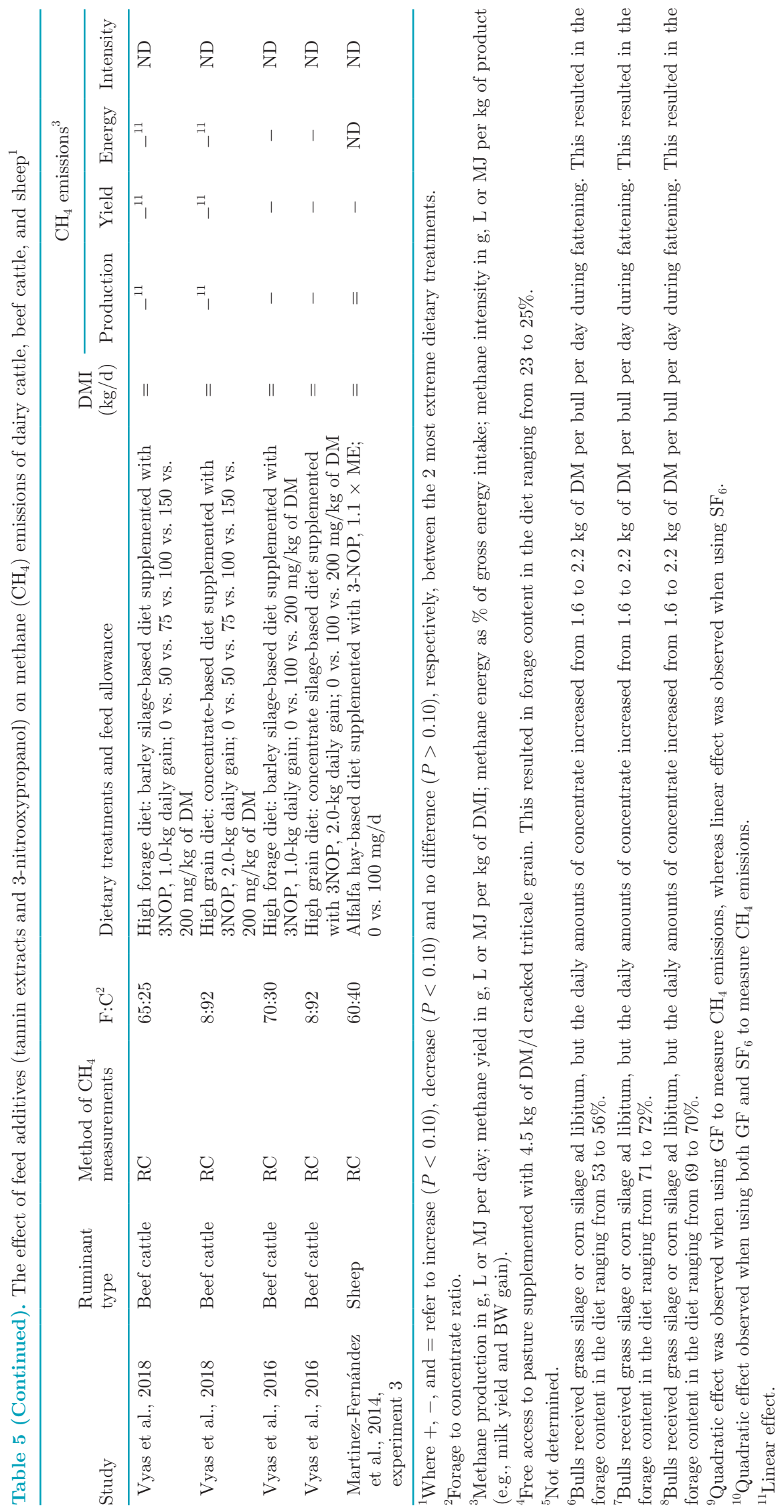


METHANE MITIGATION ACROSS RUMINANT TYPES

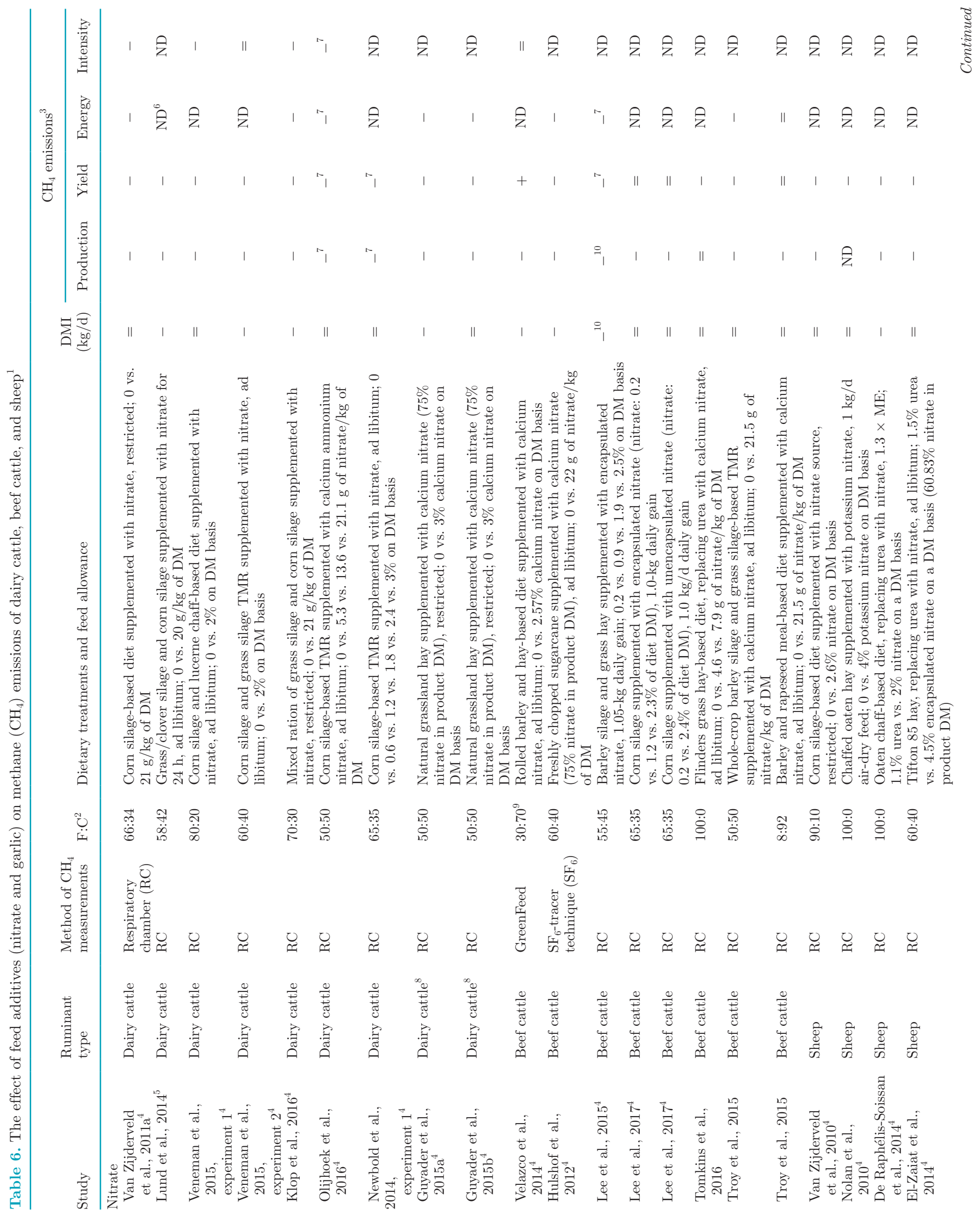




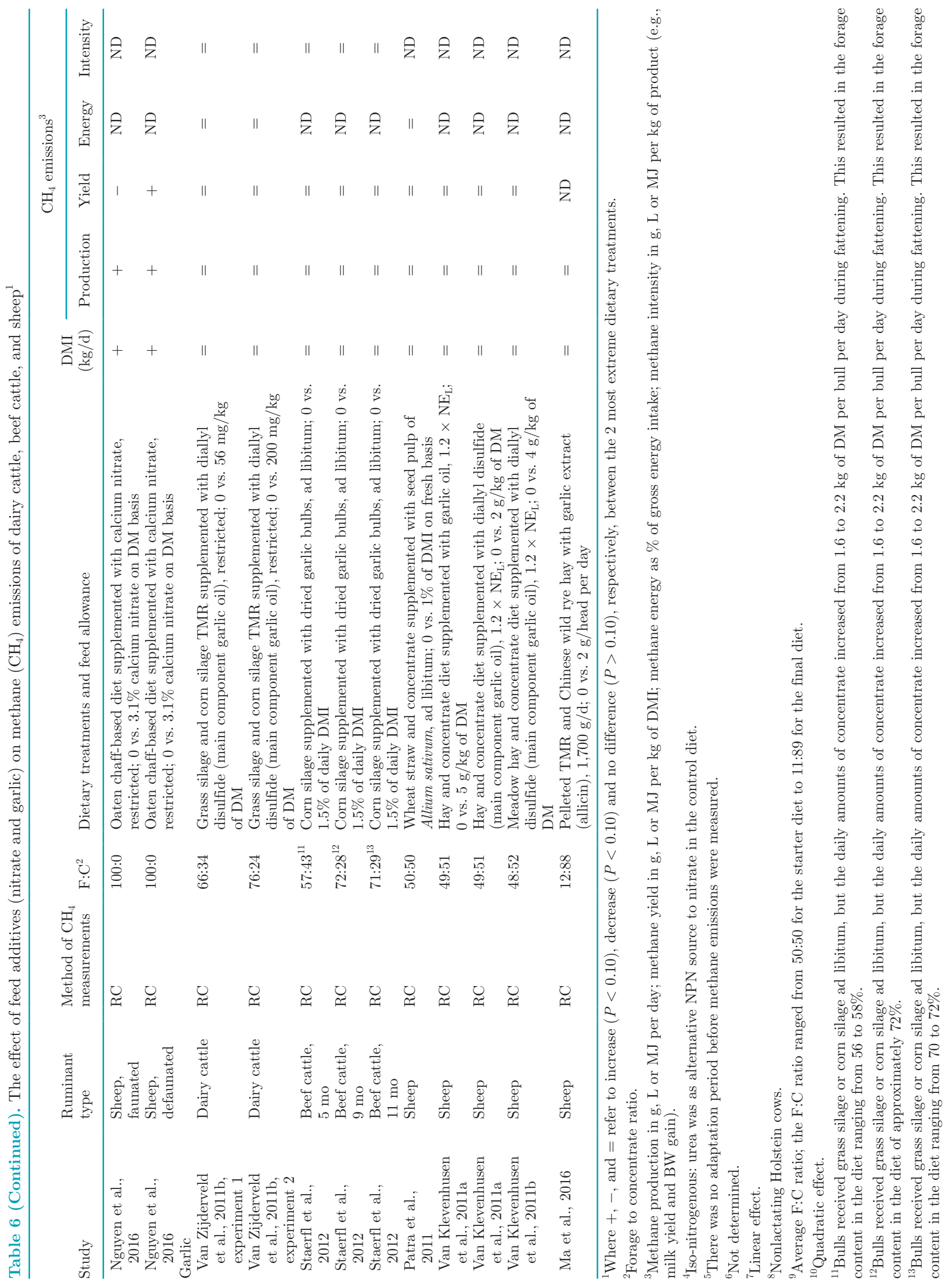


the effectiveness of increased grass (silage or herbage) or corn silage digestibly on $\mathrm{CH}_{4}$ emissions. The results for dairy cattle agree with the general assumption that forages containing a smaller concentration of structural carbohydrates, a characteristic associated with higher OMD, may result in decreased $\mathrm{CH}_{4}$ yield $(\mathrm{g} / \mathrm{kg}$ of DMI or as $\%$ of GEI) due to a shorter MRT of the feed in the rumen (Moe and Tyrrell, 1979), faster fermentation, and a trend toward increased propionate production (Pacheco et al., 2014; van Lingen et al., 2016). According to the work of Blaxter and Clapperton (1965), this inverse relationship between diet digestibility and $\mathrm{CH}_{4}$ production is valid at feeding levels of 3 times maintenance or more. Upon feeding at maintenance level, a positive linear relationship was found between diet digestibility and $\mathrm{CH}_{4}$ production. The latter relationship is in line with the findings of Pelchen and Peters (1998). With feed intake levels of sheep ranging from $0.8 \times \mathrm{ME}$ to $1.4 \times \mathrm{ME}$, those authors reported increased daily $\mathrm{CH}_{4}$ production $(\mathrm{g} / \mathrm{d})$ when OMD of the ration increased up to approximately $72 \%$ digestibility, but not when OMD increased further. Additionally, Moss et al. (1995) found a positive linear relationship between OMD and $\mathrm{CH}_{4}$ yield (as \% of GEI) for sheep fed at 1.2 times maintenance. When sheep were fed at 1.6 times maintenance, Moss et al. (1995) reported an increase in $\mathrm{CH}_{4}$ yield (\% of GEI) up to an OMD of $78 \%$, at which point any further increase in OMD resulted in a decrease in $\mathrm{CH}_{4}$ yield (\% of GEI). Overall, the above-mentioned studies support the findings in the present study for sheep, where increased $\mathrm{CH}_{4}$ yield was observed with increased OMD.

The observed difference in the effect of increased forage quality on $\mathrm{CH}_{4}$ emission across the different types of ruminants is most likely related to the differences in feed intake relative to BW. The average increase in DMI relative to BW is largest for dairy cattle, resulting in increased ruminal fermentation and subsequently increased $\mathrm{H}_{2}$ production and concentration that, by thermodynamic control of NADH oxidation, will drive end products of fermentation toward greater propionate production (van Lingen et al., 2016). This also occurs in beef cattle, but the observed increase in DMI relative to $\mathrm{BW}$ might be too small to change ruminal fermentation, $\mathrm{H}_{2}$ production, and propionate production. Sheep have a relatively low feed intake, which is also not affected by increased forage quality. This results in a relatively low and unaffected $\mathrm{H}_{2}$ concentration, and no trend toward elevated propionate production. Additionally, as stated earlier, cattle appear to digest low- to medium-quality forages to a greater extent than sheep due to the longer ruminal MRT, whereas the apparent total-tract digestibility of high-quality forages is more similar between these ruminant types. This means that an increase in forage quality increases ruminal fermentation relatively more in sheep than in cattle, resulting in relatively more $\mathrm{CH}_{4}$ production, unless a shift toward $\mathrm{H}_{2}$ sinks (i.e., propionate production) occurs. As suggested above, the latter does not seem to be the case for sheep.

\section{Different Types of Forages}

Corn Silage. Table 2 summarizes the studies that have investigated the effect of partially or completely replacing grass pasture, grass silage, or alfalfa silage with corn silage on $\mathrm{CH}_{4}$ emission from dairy cattle, beef cattle, and sheep. In dairy cattle, increased levels of corn silage resulted in increased DMI and $\mathrm{CH}_{4}$ production (11 and $8 \%$, respectively), whereas $\mathrm{CH}_{4}$ emissions generally decreased $\left[\mathrm{CH}_{4}\right.$ yield $(\mathrm{g} / \mathrm{kg}$ of DMI) $5 \%, \mathrm{CH}_{4}$ yield (\% of GEI) $7 \%$, and $\mathrm{CH}_{4}$ intensity (g/ $\mathrm{kg}$ of milk) 8\%]. This dietary strategy did not affect $\mathrm{CH}_{4}$ emission to the same extent in beef cattle; DMI generally decreased $5 \%$ with increased levels of corn silage, with $\mathrm{CH}_{4}$ production $(\mathrm{g} / \mathrm{d})$ following the same trend, and with $\mathrm{CH}_{4}$ yield $(\mathrm{g} / \mathrm{kg}$ of DMI) being unaffected. It should be noted that a critical level of dietary starch concentration appears to be required in order for this strategy to be effective in mitigating $\mathrm{CH}_{4}$ emissions from dairy or beef cattle. This is based on the quadratic responses between dietary corn silage level and $\mathrm{CH}_{4}$ emissions reported for dairy cattle (Hassanat et al., 2013; van Gastelen et al., 2015) as well as for beef cattle (Jonker et al., 2016b). Only 2 studies were available to investigate the effect of this dietary strategy on $\mathrm{CH}_{4}$ emissions from sheep, and $\mathrm{CH}_{4}$ emissions in these studies were largely unaffected by changes in dietary corn silage inclusion. The effectiveness of replacing various forage types with corn silage in reducing $\mathrm{CH}_{4}$ emissions appears to differ between dairy cattle and beef cattle. Although the results show that increasing corn silage at the expense of another forage is an effective strategy to mitigate $\mathrm{CH}_{4}$ emissions and stimulate feed intake for dairy cattle, effects observed for beef cattle are less clear. Studies on dairy and beef cattle included in the current analysis were balanced across these ruminant types with regard to the number of studies employing ad libitum or restricted feeding, as well as to those feeding diets with and without concentrate. Therefore, the difference between dairy and beef cattle in the effectiveness of reducing $\mathrm{CH}_{4}$ emissions by replacing various forage types by corn silage is likely not due to differences in feed allowance or presence of concentrate in the diet, but is instead due to the different response in DMI and apparent total-tract digestibility between these ruminant types. For dairy cattle, the increase in DMI observed with this strategy likely results in increased 
ruminal fermentation, and subsequently increased $\mathrm{H}_{2}$ production and concentration, driving end products of fermentation toward more propionate production (van Lingen et al., 2016). Additionally, if the dietary starch level is above a certain threshold (described previously), fermentation of starch favors ruminal production of propionate at the expense of acetate and decreases rumen $\mathrm{pH}$, which reduces $\mathrm{H}_{2}$ availability and activity of rumen methanogens even further (Van Kessel and Russell, 1996; Hook et al., 2011). The latter process also applies to beef cattle, but the decrease in DMI (and subsequently ruminal fermentation) might have counterbalanced this effect.

Legumes. Table 3 summarizes the studies investigating the effect of increased levels of dietary legumes on $\mathrm{CH}_{4}$ emissions from dairy cattle, beef cattle, and sheep. This section focuses only on legumes with negligible concentrations of condensed tannins (alfalfa and clover). Condensed tannins in, for example, birdsfoot trefoil and sainfoin, will be discussed in more detail in the following section. Increased levels of legumes at the expense of grass pasture or grass silage for dairy cattle resulted in increased DMI and $\mathrm{CH}_{4}$ production $(16 \%$ and $9 \%$, respectively), whereas $\mathrm{CH}_{4}$ yield decreased $\left[\mathrm{CH}_{4}\right.$ yield (g/kg of DMI) $17 \%, \mathrm{CH}_{4}$ yield (\% of GEI) $18 \%)]$ and $\mathrm{CH}_{4}$ intensity $(\mathrm{g} / \mathrm{kg}$ of milk) was unaffected. This strategy did not affect $\mathrm{CH}_{4}$ emission to the same extent in sheep; DMI generally decreased $5 \%$, with $\mathrm{CH}_{4}$ production following the same trend, but $\mathrm{CH}_{4}$ yield in $\mathrm{g} / \mathrm{kg}$ of DMI and as \% of GEI increased slightly by $2 \%$. Only 1 study was available that investigated the effect of this dietary strategy on $\mathrm{CH}_{4}$ emissions from beef cattle. In this single study, the strategy resulted in increased DMI and $\mathrm{CH}_{4}$ production and decreased $\mathrm{CH}_{4}$ yield (\% of GEI), which is qualitatively in line with dairy cattle.

These results indicate that the $\mathrm{CH}_{4}$-mitigating potential of legumes is effective in dairy cattle but not in sheep. In contrast to the dairy cattle studies describing ad libitum feeding, the sheep studies mostly involved restricted feeding. Hammond et al. (2013) offered feeds at fixed maintenance levels to sheep, and Carulla et al. (2005) suggested that the limited excess of feed offered to sheep in their study might have been insufficient to allow the full expression of potentially different voluntary feed intake. Lower feed intake of sheep when fed legumes may have led to an increase in $\mathrm{CH}_{4}$ yield, therefore masking a potential decline in $\mathrm{CH}_{4}$ emissions due to replacement of grass by legumes. Contrary to differences in feed allowance between dairy cattle and sheep (i.e., ad libitum vs. restricted, as described above), the $\mathrm{F}$ :C ratio was 100:0 in almost all studies (with the exception of Enriquez-Hidalgo et al., 2014) for both dairy cattle and sheep, and therefore does not explain the differences found in the effectiveness of legumes on $\mathrm{CH}_{4}$ mitigation between dairy cattle and sheep.

Tannin-Rich Forages. Table 3 summarizes the studies investigating the effect of increased levels of tannin-rich forages (in general; not one particular type) on $\mathrm{CH}_{4}$ emissions from dairy cattle, beef cattle, and sheep. In dairy cattle, increased levels of tannin-rich forages increased DMI 20\%, whereas $\mathrm{CH}_{4}$ production (g/d) remained unaffected, and $\mathrm{CH}_{4}$ yield $(\mathrm{g} / \mathrm{kg}$ of DMI or \% of GEI) and, if available, $\mathrm{CH}_{4}$ intensity (g/ $\mathrm{kg}$ of milk) decreased 16,11 , and $18 \%$, respectively. Similar to dairy cattle, DMI increased $34 \%$ for sheep, whereas $\mathrm{CH}_{4}$ production remained unaffected and $\mathrm{CH}_{4}$ yield (g/kg DMI and \% of GEI) decreased 23 and $36 \%$, respectively. Only 1 study investigated the effect of this dietary strategy on $\mathrm{CH}_{4}$ emissions from beef cattle and, in that study, no significant changes in $\mathrm{CH}_{4}$ emission were reported.

These results indicate that substituting grass pasture or grass silage partially or completely with tannin-rich forages decreases $\mathrm{CH}_{4}$ emissions from both dairy cattle and sheep. The $\mathrm{CH}_{4}$-mitigating effect of condensed tannins, especially when combined with grass herbage or silage, might be related to a decrease in digestibility of nutrients, and subsequently $\mathrm{H}_{2}$ formation and methanogenesis (Jayanegara et al., 2012), as well as toxicity properties suppressing both ruminal protozoa and methanogens (Tavendale et al., 2005; Bhatta et al., 2009).

\section{Forage to Concentrate Ratio}

Table 4 summarizes the studies investigating the effect of increased levels of concentrates in the diet at the expense of forage on $\mathrm{CH}_{4}$ emissions from dairy cattle, beef cattle, and sheep. Increased levels of concentrates increased DMI in cattle (19\% for dairy and $23 \%$ for beef) but not in sheep, where $\mathrm{CH}_{4}$ production $(\mathrm{g} / \mathrm{d})$ generally followed the same trend, with the exception of beef cattle where $\mathrm{CH}_{4}$ production decreased $7 \%$. Methane yield $(\mathrm{g} / \mathrm{kg}$ of DMI) generally decreased for all ruminants (6\% for sheep, $14 \%$ for dairy cattle, and $26 \%$ for beef cattle) as well as $\mathrm{CH}_{4}$ intensity (g/ $\mathrm{kg}$ of product; i.e., milk yield for dairy, ADG for beef and sheep; $10 \%$ for sheep, $27 \%$ for dairy cattle, and $31 \%$ for beef cattle). Only $\mathrm{CH}_{4}$ yield (as \% of GEI) produced contrasting results, increasing 19\% for sheep but decreasing 12 and $32 \%$ for dairy and beef cattle, respectively. The results suggest that an increasing level of concentrates is, despite differences in the feeding allowance (i.e., ad libitum feeding for dairy cattle vs. mainly restricted feeding for beef cattle and sheep), an effective $\mathrm{CH}_{4}$ mitigation strategy for dairy cattle, beef cattle, and sheep. 


\section{Feed Additives}

Tannins. Table 5 summarizes the studies investigating the effect of feeding tannin-rich extracts on $\mathrm{CH}_{4}$ emissions from dairy cattle, beef cattle, and sheep. Only 2 studies each were available to investigate the effect of this dietary strategy on $\mathrm{CH}_{4}$ emissions from dairy and beef cattle, and effects on $\mathrm{CH}_{4}$ emissions in those studies were not consistent. For sheep, DMI and daily $\mathrm{CH}_{4}$ production $(\mathrm{g} / \mathrm{d})$ were unaffected, whereas $\mathrm{CH}_{4}$ yield $(\mathrm{g} / \mathrm{kg}$ of $\mathrm{DMI})$ was decreased $13 \%$. These results indicate that tannin-rich extracts are an effective $\mathrm{CH}_{4}$ mitigation strategy for sheep. More research is required to determine the effectiveness for dairy and beef cattle, although the results of the limited number of studies appear to be promising.

3-Nitrooxypropanol. Table 5 summarizes the studies investigating the effect of feeding 3-nitrooxypropanol (3NOP) on $\mathrm{CH}_{4}$ emissions from dairy cattle, beef cattle, and sheep. Dry matter intake was not affected, whereas $\mathrm{CH}_{4}$ emissions expressed in any unit considered decreased; $\mathrm{CH}_{4}$ production $(\mathrm{g} / \mathrm{d})$ and $\mathrm{CH}_{4}$ yield (g/kg of DMI) (35\% for dairy cattle and $50 \%$ for beef cattle for both units of $\mathrm{CH}_{4}$ emission), $\mathrm{CH}_{4}$ yield (as \% of GEI; $41 \%$ for dairy cattle and $43 \%$ for beef cattle), and $\mathrm{CH}_{4}$ intensity (g/kg of milk; $25 \%$ for dairy cattle). Only 1 study investigated the effect of $3 \mathrm{NOP}$ on $\mathrm{CH}_{4}$ emissions in sheep, and found that DMI and $\mathrm{CH}_{4}$ production were not affected and $\mathrm{CH}_{4}$ yield $(\mathrm{g} / \mathrm{kg}$ of $\mathrm{DM})$ decreased upon 3NOP supply. These results illustrate that $3 \mathrm{NOP}$ is an effective $\mathrm{CH}_{4}$-mitigating feed additive for both dairy cattle and beef cattle, despite dairy cattle being mainly fed ad libitum and beef cattle being fed restricted. This is most likely because the mode of action of $3 \mathrm{NOP}$ is directly related to methanogenesis (Duin et al., 2016), a process that is similar across ruminant types. In a recent meta-analysis, Dijkstra et al. (2018) concluded that $3 \mathrm{NOP}$ indeed reduced $\mathrm{CH}_{4}$ production and yield in both dairy and beef cattle, but that the antimethanogenic effect of $3 \mathrm{NOP}$ was stronger in dairy cattle than in beef cattle when corrected for $3 \mathrm{NOP}$ dose and dietary NDF level.

Nitrate. Table 6 summarizes the studies investigating the effect of feeding nitrate on $\mathrm{CH}_{4}$ emissions from dairy cattle, beef cattle, and sheep. Dry matter intake was generally not affected for dairy cattle and sheep, whereas DMI decreased $4 \%$ in beef cattle. Decreases in $\mathrm{CH}_{4}$ production $(\mathrm{g} / \mathrm{d} ; 22 \%$ for dairy, $18 \%$ for beef, and $28 \%$ for sheep), $\mathrm{CH}_{4}$ yield (g/ $\mathrm{kg}$ of DMI; $22 \%$ for dairy, $12 \%$ for beef, and $26 \%$ for sheep), $\mathrm{CH}_{4}$ yield (as \% of GEI; $22 \%$ for dairy and $14 \%$ for beef), and $\mathrm{CH}_{4}$ intensity (g/kg of product; $20 \%$ for dairy) were consistent across ruminant types. Nitrate reduction is energetically more favorable than methanogenesis (Ungerfeld and Kohn, 2006), and the presence of nitrate in the rumen redirects $\mathrm{H}_{2}$ from methanogenesis to nitrate reduction, thereby decreasing $\mathrm{CH}_{4}$ emission (Allison and Reddy, 1984). Approximately the same proportion of the theoretical $\mathrm{CH}_{4}$ reduction potential of nitrate was reached for dairy cattle $(72 \%)$, beef cattle $(72 \%)$, and sheep (74\%), indicating that the same amount of nitrate was reduced to ammonia across different types of ruminants.

Garlic. Garlic oil is known to possess antimicrobial properties and has been shown to decrease $\mathrm{CH}_{4}$ production in vitro (García-Martínez et al., 2005; Chaves et al., 2008). This also applies to the main component of garlic oil; namely, diallyl disulfide (Busquet et al., 2005 ). Despite the great potential demonstrated in vitro, none of the in vivo studies in the present overview found a $\mathrm{CH}_{4}$-mitigating effect when feeding garlic, or any of its components, to dairy cattle, beef cattle, or sheep (Table 6). Given these consistent results across ruminant types, we conclude that garlic is an ineffective strategy to reduce $\mathrm{CH}_{4}$ emission.

\section{CONCLUSIONS}

The effectiveness of forage-related $\mathrm{CH}_{4}$ mitigation strategies, including feeding grass (herbage or silage) with increased levels of digestibility or replacing different forage types with corn silage, differs across dairy cattle, beef cattle, and sheep. These strategies are most effective for dairy cattle, are effective to some extent for beef cattle, but have no or minor effects in sheep. This is most likely due to differences in feed intake level and rumen physiology between the different types of ruminants. In general, the effectiveness of other dietary $\mathrm{CH}_{4}$ mitigation strategies, including increased concentrate feeding and the use of feed additives (e.g., nitrate), appears to be similar for dairy cattle, beef cattle, and sheep. This illustrates that the modes of action of these strategies are independent of differences in feed intake, rumen physiology, and fermentation characteristics across ruminant types. Therefore, we conclude that if the mode of action of a dietary $\mathrm{CH}_{4}$ mitigation strategy is directly associated with methanogenesis-related fermentation pathways, the strategy is more likely to have a similar effect across different types of ruminants. If the mode of action of a dietary $\mathrm{CH}_{4}$ mitigation strategy is related to ruminant-specific factors such as feed intake or rumen physiology, the effectiveness of the strategy is more likely to differ between ruminant types. Subsequently, reductions in $\mathrm{CH}_{4}$ emission obtained in one type of ruminant may not apply to other ruminant types, as observed in the present study. 


\section{ACKNOWLEDGMENTS}

The authors acknowledge Kelly Nichols (Wageningen, the Netherlands) for assistance in editing the manuscript for the correct use of English. Authors acknowledge the project "Low Emission Animal Feed" (BO-12.02-009-004), which received financial support of the Dutch Ministry of Economic Affairs (The Hague, the Netherlands), Product Board Animal Feed (Zoetermeer, the Netherlands), and the Dutch Dairy Board (Zoetermeer, the Netherlands). The authors also acknowledge the financial support Sanne van Gastelen and André Bannink received from the Dutch Ministry of Agriculture, Nature and Food Quality (PPS project AF-EU-18010) and The Netherlands Organisation for Scientific Research (ALW.GAS.2) under the ERA-NET Cofund scheme ERAGAS (CEDERS project).

\section{REFERENCES}

Aerts, J. V., J. L. De Boever, B. G. Cottyn, D. L. De Brabander, and F. X. Buysse. 1984. Comparative digestibility of feedstuffs by sheep and cows. Anim. Feed Sci. Technol. 12:47-56.

Aguerre, M. J., M. A. Wattiaux, J. M. Powell, G. A. Broderick, and C. Arndt. 2011. Effect of forage-to-concentrate ratio in dairy cow diets on emission of methane, carbon dioxide, and ammonia, lactation performance, and manure excretion. J. Dairy Sci. 94:3081-3093.

Alexander, R. A., J. F. Hentges Jr., J. T. McCall, and W. O. Ash. 1962. Comparative digestibility of nutrients in roughages by cattle and sheep. J. Anim. Sci. 21:373-376.

Allison, M. J., and C. A. Reddy. 1984. Adaptations of gastrointestinal bacteria in response to changes in dietary oxlalate and nitrate. Pages 248-256 in Current Perspectives in Microbial Ecology: Proceedings of the Third International Symposium of Microbial Ecology, Washington, DC. M. J. Klug and C. A. Reddy, ed. American Society for Microbiology, Washington, DC.

Amaral, G. A., D. B. David, J. I. Gere, J. V. Savian, M. M. Kohmann, L. B. Nadin, F. Sánchez Chopa, C. Bayer, and P. C. F. Carvalho. 2016. Methane emissions from sheep grazing pearl millet (Penisetum americanum (L.) Leeke) swards fertilized with increasing nitrogen levels. Small Rumin. Res. 141:118-123.

Archimède, H., M. Rira, D. J. Barde, F. Labirin, C. Marie-Magdeleine, B. Calif, F. Periacarpin, J. Fleury, Y. Rochette, D. P. Morgavi, and M. Doreau. 2016. Potential of tannin-rich plants, Leucaena leucocephala, Glyricidia sepium and Manihot esculenta, to reduce enteric methane emissions in sheep. J. Anim. Physiol. Anim. Nutr. (Berl.) 100:1149-1158.

Armstrong, D. G. 1964. Evaluation of artificially dried grasses as a source of energy for sheep. J. Agric. Sci. 62:399-416.

Arndt, C., J. M. Powell, M. J. Aguerre, and M. A. Wattiaux. 2015. Performance, digestion, nitrogen balance, and emission of manure ammonia, enteric methane, and carbon dioxide in lactating cows fed diets with varying alfalfa silage-to-corn silage ratios. J. Dairy Sci. 98:418-430.

Beauchemin, K. A., and S. M. McGinn. 2005. Methane emissions from feedlot cattle fed barley or corn diets. J. Anim. Sci. 83:653-661.

Beauchemin, K. A., S. M. McGinn, T. F. Martinez, and T. A. McAllister. 2007. Use of condensed tannin extract from quebracho trees to reduce methane emissions from cattle. J. Anim. Sci. 85:1990-1996.

Benchaar, C., F. Hassanat, R. Gervais, P. Y. Chouinard, H. V. Petit, and D. I. Massé. 2014. Methane production, digestion, ruminal fermentation, nitrogen balance, and milk production of cows fed corn silage- or barley silage-based diets. J. Dairy Sci. 97:961-974.

Bhatta, R., Y. Uyeno, K. Tajima, A. Takenaka, Y. Yabumoto, I. Nonaka, O. Enishi, and M. Kurihara. 2009. Difference in the nature of tannins on in vitro ruminal methane and volatile fatty acid production and on methanogenic archaea and protozoal populations. J. Dairy Sci. 92:5512-5522.

Blaxter, K. L., and J. L. Clapperton. 1965. Prediction of the amount of methane produced by ruminants. Br. J. Nutr. 19:511-522.

Blaxter, K. L., and F. W. Wainman. 1961. The utilization of food by sheep and cattle. J. Agric. Sci. 57:419-425.

Blaxter, K. L., F. W. Wainman, and J. L. Davidson. 1966. The voluntary intake of food by sheep and cattle in relation to their energy requirements for maintenance. Anim. Prod. 8:75-83.

Boadi, D. A., and K. M. Wittenberg. 2002. Methane production from dairy and beef heifers fed forages differing in nutrient density using the sulphur hexafluoride (SF6) tracer gas technique. Can. J. Anim. Sci. 82:201-206.

Brask, M., P. Lund, A. L. F. Hellwing, M. Poulsen, and M. R. Weisbjerg. 2013. Enteric methane production, digestibility and rumen fermentation in dairy cows fed different forages with and without rapeseed fat supplementation. Anim. Feed Sci. Technol. 184:67-79.

Busquet, M., S. Calsamiglia, A. Ferret, M. D. Carro, and C. Kamel. 2005. Effect of garlic oil and four of its compounds on rumen microbial fermentation. J. Dairy Sci. 88:4393-4404.

Cammell, S. B., J. D. Sutton, D. E. Beever, D. J. Humphries, and R. H. Phipps. 2000. The effect of crop maturity on the nutritional value of maize silage for lactating dairy cows 1. Energy and nitrogen utilization. Anim. Sci. 71:381-390.

Carulla, J. E., M. Kreuzer, A. Machmüller, and H. D. Hess. 2005. Supplementation of Acacia mearnsii tannins decreases methanogenesis and urinary nitrogen in forage-fed sheep. Aust. J. Agric. Res. 56:961-970.

Chaves, A. V., M. L. He, W. Z. Yang, A. N. Hristov, T. A. McAllister, and C. Benchaar. 2008. Effects of essential oils on proteolytic, deaminative and methanogenic activities of mixed ruminal bacteria. Can. J. Anim. Sci. 88:117-122.

Colucci, P. E., G. K. Macleod, W. L. Grovum, L. W. Cahill, and I McMillan. 1989. Comparative digestion in sheep and cattle fed different forage to concentrate ratios at high and low intakes. J. Dairy Sci. 72:1774-1785.

Colucci, P. E., G. K. Macleod, W. L. Grovum, I. McMillan, and D. J. Barney. 1990. Digesta kinetics in sheep and cattle fed diets with different forage to concentrate ratios at high and low intakes. J. Dairy Sci. 73:2143-2156.

De Oliveira, S. G., T. T. Berchielli, M. dos Santos Pedreira, O. Primavesi, R. Prighetto, and M. A. Lima. 2007. Effect of tannin levels in sorghum silage and concentrate supplementation on apparent digestibility and methane emission in beef cattle. Anim. Feed Sci Technol. 135:236-248.

De Raphélis-Soissan, V., L. Li, I. R. Godwin, M. C. Barnett, H. B Perdok, and R. S. Hegarty. 2014. Use of nitrate and Propionibacterium acidipropionici to reduce methane emissions and increase wool growth of Merino sheep. Anim. Prod. Sci. 54:1860-1866.

Delgado, D. C., J. Galindo, J. Cairo, I. Orta, M. Dominquez, and N. Dorta. 2013. Supplementation with foliage of L. leucocephala. Its effect on the apparent digestibility of nutrients and methane production in sheep. Cuban J. Agric. Sci. 47:267-271.

Dijkstra, J., A. Bannink, J. France, E. Kebreab, and S. van Gastelen. 2018. Short communication: Antimethanogenic effects of 3-nitrooxypropanol depend on supplementation dose, dietary fiber content, and cattle type. J. Dairy Sci. 101:9041-9047.

Dini, Y., J. I. Gere, C. Cajarville, and V. S. Ciganda. 2017. Using highly nutritious pastures to mitigate enteric methane emissions from cattle grazing systems in South America. Anim. Prod. Sci https://doi.org/10.1071/AN16803.

Doreau, M., A. Ferlay, Y. Rochette, and C. Martin. 2014. Effects of dehydrated lucerne and soya bean meal on milk production and composition, nutrient digestion, and methane and nitrogen losses in dairy cows receiving two different forages. Animal 8:420-430.

Doreau, M., H. M. G. van der Werf, D. Micol, H. Dubroeucq, J. Agabriel, Y. Rochette, and C. Martin. 2011. Enteric methane production and greenhouse gases balance of diets differing in concentrate in the fattening phase of a beef production system. J. Anim. Sci $89: 2518-2528$ 
Duin, E. C., T. Wagner, S. Shima, D. Prakash, B. Cronin, D. R. Yáñez-Ruiz, S. Duval, R. Rümbeli, R. T. Stemmler, R. K. Thauer, and M. Kindermann. 2016. Mode of action uncovered for the specific reduction of methane emissions from ruminants by the small molecule 3-nitrooxypropanol. Proc. Natl. Acad. Sci. USA 113:6172-6177.

Duval, B. D., M. Aguerre, M. Wattiaux, P. A. Vadas, and J. M. Powell. 2016. Potential for reducing on-farm greenhouse gas and ammonia emissions from dairy cows with prolonged dietary tannin additions. Water Air Soil Pollut. 227:329.

El-Zaiat, H. M., R. C. Araujo, Y. A. Soltan, A. S. Morsy, H. Louvandini, A. V. Pires, H. O. Patino, P. S. Correa, and A. L. Abdalla. 2014. Encapsulated nitrate and cashew nut shell liquid on blood and rumen constituents, methane emission, and growth performance of lambs. J. Anim. Sci. 92:2214-2224.

Enriquez-Hidalgo, D., T. Gilliland, M. H. Deighton, M. O'Donovan, and D. Hennessy. 2014. Milk production and enteric methane emissions by dairy cows grazing fertilized perennial ryegrass pasture with or without inclusion of white clover. J. Dairy Sci. 97:1400-1412.

Ferris, C. P., F. J. Gordon, D. C. Patterson, M. G. Porter, and T. Yan. 1999. The effect of genetic merit and concentrate proportion in the diet on nutrient utilization by lactating dairy cows. J. Agric. Sci. 132:483-490.

Fievez, V., F. Piattoni, L. Mbanzamihigo, and D. Demeyer. 1999. Reductive acetogenesis in the hindgut and attempts to its induction in the rumen-A review. J. Appl. Anim. Res. 16:1-22.

García-Martínez, R., M. J. Ranilla, M. L. Tejido, and M. D. Carro. 2005. Effects of disodium fumarate on in vitro rumen microbial growth, methane production and fermentation of diets differing in their forage:concentrate ratio. Br. J. Nutr. 94:71-77.

Gerber, P. J., A. Mottet, C. I. Opio, A. Falcucci, and F. Teillard. 2015. Environmental impacts of beef production: Review of challenges and perspectives for durability. Meat Sci. 109:2-12.

Goopy, J. P., A. Donaldson, R. Hegarty, P. E. Vercoe, F. Haynes, M. Barnett, and V. H. Oddy. 2014. Low-methane yield sheep have smaller rumens and shorter rumen retention time. Br. J. Nutr. 111:578-585.

Gordon, F. J., M. G. Porter, C. S. Maybe, E. F. Unsworth, and D. J. Kilpatrick. 1995. Effect of forage digestibility and type of concentrate on nutrient utilization by lactating dairy cattle. J. Dairy Res. 62:15-27.

Grainger, C., T. Clarke, M. J. Auldist, K. A. Beauchemin, S. M. McGinn, G. C. Waghorn, and R. J. Eckard. 2009. Potential use of Acacia mearnsii condensed tannins to reduce methane emissions and nitrogen excretion from grazing dairy cows. Can. J. Anim. Sci. 89:241-251.

Grovum, W. L., and V. J. Williams. 1977. Rate of passage of digesta in sheep. 6. The effect of level of food intake on mathematical predictions of the kinetics of digesta in the reticulorumen and intestines. Br. J. Nutr. 38:425-436.

Günal, M., A. McCourt, Y. Zhao, Z. G. Yan, and T. Yan. 2018. The effect of silage type on animal performance, energy utilisation and enteric methane emission in lactating dairy cows. Anim. Prod. Sci. https://doi.org/10.1071/AN16435.

Guyader, J., M. Eugène, M. Doreau, D. P. Morgavi, C. Gérard, C. Loncke, and C. Martin. 2015a. Nitrate but not tea saponin feed additives decreased enteric methane emissions in nonlactating cows. J. Anim. Sci. 93:5367-5377.

Guyader, J., M. Eugène, B. Meunier, M. Doreau, D. P. Morgavi, M. Silberberg, Y. Rochette, C. Gérard, C. Loncke, and C. Martin. 2015b. Additive methane-mitigating effect between linseed oil and nitrate fed to cattle. J. Anim. Sci. 93:3564-3577.

Haisan, J., Y. Sun, L. Guan, K. A. Beauchemin, A. Iwaasa, S. Duval, M. Kindermann, D. R. Barreda, and M. Oba. 2017. The effects of feeding 3-nitrooxypropanol at two doses on milk production, rumen fermentation, plasma metabolites, nutrient digestibility, and methane emissions in lactating Holstein cows. Anim. Prod. Sci. $57: 282-289$.

Haisan, J., Y. Sun, L. L. Guan, K. A. Beauchemin, A. Iwaasa, S. Duval, D. R. Barreda, and M. Oba. 2014. The effects of feeding 3-ni- trooxypropanol on methane emissions and productivity of Holstein cows in mid lactation. J. Dairy Sci. 97:3110-3119.

Hammond, K. J., J. L. Burke, J. P. Koolaard, S. Muetzel, C. S. Pinares-Patiño, and G. C. Waghorn. 2013. Effects of feed intake on enteric methane emissions from sheep fed fresh white clover (Trifolium repens) and perennial ryegrass (Lolium perenne) forages. Anim. Feed Sci. Technol. 179:121-132.

Hart, K. J., P. G. Martin, P. A. Foley, D. A. Kenny, and T. M. Boland. 2009. Effect of sward dry matter digestibility on methane production, ruminal fermentation, and microbial populations of zero-grazed beef cattle. J. Anim. Sci. 87:3342-3350.

Hassanat, F., R. Gervais, C. Julien, D. I. Massé, A. Lettat, P. Y. Chouinard, H. V. Petit, and C. Benchaar. 2013. Replacing alfalfa silage with corn silage in dairy cow diets: Effects on enteric methane production, ruminal fermentation, digestion, $\mathrm{N}$ balance, and milk production. J. Dairy Sci. 96:4553-4567.

Hatew, B., A. Bannink, H. van Laar, L. H. de Jonge, and J. Dijkstra. 2016. Increasing harvest maturity of whole-plant corn silage reduces methane emission of lactating dairy cows. J. Dairy Sci. 99:354-368.

Henderson, G., F. Cox, S. Ganesh, A. Jonker, W. YoungGlobal Rumen Census Collaborators, and P. H. Janssen. 2015. Rumen microbial community composition varies with diet and host, but a core microbiome is found across a wide geographical range. Sci. Rep. 5:14567.

Hess, H. D., T. T. Tiemann, F. Noto, J. E. Carulla, and M. Kreuzer. 2006. Strategic use of tannins as means to limit methane emission from ruminant livestock. Int. Congr. Ser. 1293:164-167.

Hindrichsen, I. K., H.-R. Wettstein, A. Machmüller, and M. Kreuzer. 2006. Methane emission, nutrient degradation and nitrogen turnover in dairy cows and their slurry at different milk production scenarios with and without concentrate supplementation. Agric. Ecosyst. Environ. 113:150-161.

Hook, S. E., M. Steele, K. Northwood, A.-D. Wright, and B. McBride. 2011. Impact of high-concentrate feeding and low ruminal $\mathrm{pH}$ on methanogens and protozoa in the rumen of dairy cows. Microb. Ecol. 62:94-105.

Hristov, A. N., J. Oh, J. L. Firkins, J. Dijkstra, E. Kebreab, G. Waghorn, H. P. S. Makkar, A. T. Adesogan, W. Yang, C. Lee, P. J. Gerber, B. Henderson, and J. M. Tricarico. 2013a. Mitigation of methane and nitrous oxide emissions from animal operations: I. A review of enteric methane mitigation options. J. Anim. Sci 91:5045-5069.

Hristov, A. N., J. Oh, F. Giallongo, T. W. Frederick, M. T. Harper, H. L. Weeks, A. F. Branco, P. J. Moate, M. H. Deighton, S. R. Williams, M. Kindermann, and S. Duval. 2015. Use of 3-nitrooxypropanol as feed additive for mitigating enteric methane emissions from ruminants: a meta-analysis. Proc. Natl. Acad. Sci. USA 112:10663-10668.

Hristov, A. N., T. Ott, J. Tricarico, A. Rotz, G. Waghorn, A. Adesogan, J. Dijkstra, F. Montes, J. Oh, E. Kebreab, S. J. Oosting, P. J. Gerber, B. Henderson, H. P. S. Makkar, and J. L. Firkins. 2013b. Mitigation of methane and nitrous oxide emissions from animal operations: III. A review of animal management mitigation options. J. Anim. Sci. 91:5095-5113.

Hulshof, R. B. A., A. Berndt, W. J. J. Gerrits, J. Dijkstra, S. M. van Zijderveld, J. R. Newbold, and H. R. Perdok. 2012. Dietary nitrate supplementation reduces methane emission in beef cattle fed sugarcane-based diets. J. Anim. Sci. 90:2317-2323.

Huyen, N. T., O. Desrues, S. J. J. Alferink, T. Zandstra, M. W. A. Verstegenm, W. H. Hendriks, and W. F. Pellikaan. 2016. Inclusion of sainfoin (Onobrychis viciifolia) silage in dairy cow rations affects nutrient digestibility, nitrogen utilization, energy balance and methane emissions. J. Dairy Sci. 99:3566-3577.

Jayanegara, A., F. Leiber, and M. Kreuzer. 2012. Meta-analysis of the relationship between dietary tannin level and methane formation in ruminants from in vivo and in vitro experiments. J. Anim. Physiol. Anim. Nutr. (Berl.) 96:365-375.

Jeyanathan, J., M. Kirs, R. S. Ronimus, S. O. Hoskin, and P. J. Janssen. 2011. Methanogen community structure in the rumens of 
farmed sheep: cattle and red deer fed different diets. FEMS Microbiol. Ecol. 76:311-326.

Jonker, A., K. Lowe, S. Kittelman, P. H. Janssen, S. Ledgard, and D. Pachego. 2016b. Methane emissions changed nonlinearly with graded substitution of alfalfa silage with corn silage and corn grain in the diet of sheep and relation with rumen fermentation characteristics in vivo and in vitro. J. Anim. Sci. 94:3464-3475.

Jonker, A., S. Muetzel, G. Molano, and D. Pacheco. 2016a. Effect of fresh pasture quality, feeding level and supplementation on methane emissions from growing beef cattle. Anim. Prod. Sci. 56:17141721.

Klop, G., B. Hatew, A. Bannink, and J. Dijkstra. 2016. Feeding nitrate and docosahexaenoic acid affects enteric methane production and milk fatty acid composition in lactating dairy cows. J. Dairy Sci. 99:1161-1172.

Lage, J. F., E. San Vito, R. A. Reis, E. E. Dallantonia, L. R. Simonetti, I. P. C. Carvalho, A. Berndt, M. L. Chizzotti, R. T. S. Friguetto, and T. T. Berchielli. 2016. Methane emissions and growth performance of young Nellore bulls fed crude glycerine- v. fibre-based energy ingredients in low or high concentrate diets. J. Agric. Sci. 154:1280-1290.

Leaver, J. D., R. C. Campling, and W. Holmes. 1969. The effect of level of feeding on the digestibility of diets for sheep and cattle. Anim. Sci. 11:11-18.

Lechner-Doll, M., M. Kaske, and W. van Engelhardt. 1991. Factors affecting the mean retention time of particles in the forestomach of ruminants and camelids. Pages 455-482 in Physiological Aspects of Digestion and Metabolism of Ruminants: Proc. 7th Int. Symp. Ruminant Physiology. T. Tsuda, Y. Sasaki, and R. Kawashima, ed. Academic Press Inc., San Diego, CA.

Lee, C., R. C. Araujo, K. M. Koenig, and K. A. Beauchemin. 2015 Effects of encapsulated nitrate on enteric methane production and nitrogen and energy utilization in beef heifers. J. Anim. Sci. 93:2391-2404

Lee, C., R. C. Araujo, K. M. Koenig, and K. A. Beauchemin. 2017. Effects of encapsulated nitrate on growth performance, nitrate toxicity, and enteric methane emissions in beef steers: Backgrounding phase. J. Anim. Sci. 95:3700-3711.

Lee, J. M., S. L. Woodward, G. C. Waghorn, and D. A. Clark. 2004. Methane emissions by dairy cows fed increasing proportions of white clover (Trifolium repens) in pasture. Proc. N.Z. Grassland Assoc. 66:151-155.

Lindberg, J. E. 1985. Estimation of rumen degradability of feed proteins with the sacco technique and various vitro methods: A review. Acta Agric. Scand. Suppl. 25:64-79.

Lindberg, J. E. 1988. Retention times of small feed particles and of water in the gut of dairy goats fed at different levels of intake. J. Anim. Physiol. Anim. Nutr. (Berl.) 59:173-181.

Liu, C., Z. P. Zhu, B. Shang, Y. X. Chen, T. J. Guo, Y. M. Luo, and H. M. Dong. 2012. Effects of dietary types or concentrate-to-forage ratios on rumen methane emissions of sheep. ILES12-0599 in Proc. IX International Livestock Environment Symposium (ILES IX), Valencia, Spain. American Society of Agricultural and Biological Engineers, St. Joseph, MI.

Lopes, J. C., L. F. de Matos, M. T. Harper, F. Giallongo, J. Oh, D. Gruen, S. Ono, M. Kindermann, S. Duval, and A. N. Hristov. 2016. Effect of 3-nitrooxypropanol on methane and hydrogen emissions, methane isotopic signature, and ruminal fermentation in dairy cows. J. Dairy Sci. 99:5335-5344.

Lovett, D., S. Lovell, L. Stack, J. Callan, M. Finlay, J. Conolly, and F. P. O'Mara. 2003. Effect of forage/concentrate ratio and dietary coconut oil level on methane output and performance of finishing beef heifers. Livest. Prod. Sci. 84:135-146.

Lovett, D. K., L. J. Stack, S. Lovell, J. Callan, B. Flynn, M. Hawkins, and F. P. O'Mara. 2005. Manipulating enteric methane emissions and animal performance of late-lactation dairy cows through concentrate supplementation at pasture. J. Dairy Sci. 88:2836-2842.

Lund, P., R. Dahl, H. J. Yng, A. L. F. Hellwing, B. B. Cao, and M. R. Weisbjerg. 2014. The acute effect of addition of nitrate on in vitro and in vivo methane emission in dairy cows. Anim. Prod. Sci. 54:1432-1435.
Ma, T., D. Chen, Y. Tu, N. Zhang, B. Si, K. Deng, and Q. Diao. 2016. Effect of supplementation of allicin on methanogenesis and ruminal microbial flora in Dorper crossbred ewes. J. Anim. Sci. Biotechnol. 7:1.

Margan, D. E., J. B. Moran, and F. B. Spence. 1994. Energy and protein value of combinations of maize silage and red clover hay for ruminants, using adult sheep as a model. Aust. J. Exp. Agric. 34:319-329.

Martin, C., D. P. Morgavi, and M. Doreau. 2010. Methane mitigation in ruminants: From microbe to the farm scale. Animal 4:351-365.

Martínez-Fernández, G., L. Abecia, A. Arco, G. Cantalapiedra-Hijar, A. I. Martín-García, E. Molina-Alcaide, M. Kindermann, S. Duval, and D. R. Yáñez-Ruiz. 2014. Effects of ethyl-3-nitrooxy propionate and 3-nitrooxypropanol on ruminal fermentation, microbial abundance, and methane emissions in sheep. J. Dairy Sci. 97:3790-3799.

Mc Geough, E. J., P. O'Kiely, P. A. Foley, K. J. Hart, T. M. Boland, and D. A. Kenny. 2010a. Methane emissions, feed intake, and performance of finishing beef cattle offered maize silages harvested at 4 different stages of maturity. J. Anim. Sci. 88:1479-1491.

Mc Geough, E. J., P. O'Kiely, K. J. Hart, A. P. Moloney, T. M. Boland, and D. A. Kenny. 2010b. Methane emissions, feed intake, performance, digestibility, and rumen fermentation of finishing beef cattle offered whole-crop wheat silages differing in grain content. J. Anim. Sci. 88:2703-2716.

McAllister, T. A., and C. J. Newbold. 2008. Redirecting rumen fermentation to reduce methanogenesis. Aust. J. Exp. Agric. 48:7-13.

McCaughey, W. P., K. Wittenberg, and D. Corrigan. 1999. Impact of pasture type on methane production by lactating beef cows. Can. J. Anim. Sci. 79:221-226.

McCourt, A. R., T. Yan, and C. S. Mayne. 2007. Effect of forage type on methane production from dairy cows. Page 048 in Proc. Br. Soc. Anim. Sci., Southport, UK. Cambridge University Press, Cambridge, UK.

McDonald, P., R. A. Edwards, J. F. D. Greenhaulgh, and C. A. Morgan. 2002. Animal Nutrition. Pearson Prentice Hall, Harlow, UK.

Moe, P. W., and H. F. Tyrrell. 1979. Methane production in dairy cows. J. Dairy Sci. 62:1583-1586.

Molano, G., and H. Clark. 2008. The effect of level of intake and forage quality on methane production by sheep. Aust. J. Exp. Agric. $48: 219-222$.

Moss, A. R., D. I. Givens, and P. C. Garnworthy. 1995. The effect of supplementing grass silage with barley on digestibility, in sacco degradability, rumen fermentation and methane production in sheep at two levels of intake. Anim. Feed Sci. Technol. 55:9-33.

Murray, R. M., A. M. Bryant, and R. A. Leng. 1976. Rates of production of methane in the rumen and large intestine of sheep. Br. J. Nutr. 36:1-14.

Newbold, J. R., S. M. van Zijderveld, R. B. A. Hulshof, W. B. Fokkink, R. A. Leng, P. Terencio, W. J. Powers, P. S. J. van Adrichem, N D. Paton, and H. R. Perdok. 2014. The effect of incremental levels of dietary nitrate on methane emissions in Holstein steers and performance in Nelore bulls. J. Anim. Sci. 92:5032-5040.

Nguyen, S. H., M. C. Barnett, and R. S. Hegarty. 2016. Use of dietary nitrate to increase productivity and reduce methane production of defaunated and faunated lambs consuming protein-deficient chaff. Anim. Prod. Sci. 56:290-297.

Nocek, J. E. 1988. In situ and other methods to estimate ruminal protein and energy digestibility: A review. J. Dairy Sci. 71:2051-2069.

Nolan, J. V., R. S. Hegarty, J. Hegarty, I. R. Godwin, and R. Woodgate. 2010. Effects of dietary nitrate on fermentation, methane production and digesta kinetics in sheep. Anim. Prod. Sci. 50:801806.

Norton, B. W., H. Pieris, and R. Elliott. 1994. Fermentation pattern and diet utilization by cattle, sheep and goats given grain or molasses based diets. Proc. Australas. Soc. Anim. Prod. 20:182-185.

Okine, E. K., G. W. Mathison, and R. T. Hardin. 1989. Effects of changes in frequency of reticular contractions on fluid and particulate passage rates in cattle. J. Anim. Sci. 67:3388-3396.

Olijhoek, D. W., A. L. F. Hellwing, M. Brask, M. R. Weisbjerg, O Højberg, M. K. Larsen, J. Dijkstra, E. J. Erlandsen, and P. Lund 2016. Effect of dietary nitrate level on enteric methane production, 
hydrogen emission, rumen fermentation, and nutrient digestibility in dairy cows. J. Dairy Sci. 99:6191-6205.

Pacheco, D., G. Waghorn, and P. H. Janssen. 2014. Decreasing methane emissions from ruminants grazing forages: A fit with productive and financial realities? Anim. Prod. Sci. 54:1141-1154.

Patra, A. K., D. N. Kamra, R. Bhar, R. Kumar, and N. Agarwal. 2011. Effect of Terminalia chebula and Allium sativum on in vivo methane emission by sheep. J. Anim. Physiol. Anim. Nutr. (Berl.) 95:187-191.

Pearson, R. A., R. F. Archibald, and R. H. Muirhead. 2006. A comparison of the effect of forage type and level of feeding on the digestibility and gastrointestinal mean retention time of dry forages given to cattle, sheep, ponies and donkeys. Br. J. Nutr. 95:88-98.

Pelchen, A., and K. J. Peters. 1998. Methane emissions from sheep. Small Rumin. Res. 27:137-150.

Pinares-Patiño, C. S., R. Baumont, and C. Martin. 2003. Methane emissions by Charolais cows grazing a monospecific pasture of timothy at four stages of maturity. Can. J. Anim. Sci. 83:769-777.

Poppi, D. P., D. J. Minson, and J. H. Ternouth. 1980. Studies of cattle and sheep eating leaf and stem fractions of grasses. I. The voluntary intake, digestibility and retention time in the reticulo-rumen. Aust. J. Agric. Res. 32:99.

Poppi, D. P., D. J. Minson, and J. H. Ternouth. 1981. Studies of cattle and sheep eating leaf and stem fractions of grasses. 11. Factors controlling the retention of feed in the reticulo-rumen. Aust. J. Agric. Res. 32:109-121.

Potts, S. B., M. Shaughness, and R. A. Erdman. 2017. The decline in digestive efficiency of US dairy cows from 1970 to 2014. J. Dairy Sci. 100:5400-5410.

Prigge, E. C., M. J. Baker, and G. A. Varga. 1984. Comparative digestion rumen fermentation and kinetics of forage diets by steers and wethers. J. Anim. Sci. 59:237-245.

Rees, M. C., and D. A. Little. 1980. Differences between sheep and cattle in digestibility, voluntary intake and retention time in the rumen of three tropical grasses. J. Agric. Sci. (Camb.) 94:483-485.

Reid, R. L., G. A. Jung, J. M. Cox-Ganser, B. F. Rybeck, and E. C. Townsend. 1990. Comparitive utilization of warm- and cool-season forages by cattle, sheep and goats. J. Anim. Sci. 68:2986-2994.

Reynolds, C. K., L. A. Crompton, J. A. N. Mills, D. J. Humphries, P. Kirton, A. E. Relling, T. H. Misselbrook, D. R. Chadwick, and D. I. Givens. 2010. Effects of diet protein level and forage source on energy and nitrogen balance and methane and nitrogen excretion in lactating dairy cows. Pages 463-464 in Proc. 3rd EAAP International Symposium on Energy and Protein Metabolism and Nutrition. G. M. Crovetto, ed. Wageningen Academic Publishers, Parma, Italy.

Reynolds, C. K., D. J. Humphries, P. Kirton, M. Kindermann, S. Duval, and W. Steinberg. 2014. Effects of 3-nitrooxypropanol on methane emission, digestion, and energy and nitrogen balance of lactating dairy cows. J. Dairy Sci. 97:3777-3789.

Romero-Perez, A., E. K. Okine, S. M. McGinn, L. L. Guan, M. Oba, S. M. Duval, M. Kindermann, and K. A. Beauchemin. 2014. The potential of 3-nitrooxypropanol to lower enteric methane emissions from beef cattle. J. Anim. Sci. 92:4682-4693.

Romero-Perez, A., E. K. Okine, S. M. McGinn, L. L. Guan, M. Oba, S. M. Duval, M. Kindermann, and K. A. Beauchemin. 2015. Sustained reduction in methane production from long-term addition of 3-nitrooxypropanol to a beef cattle diet. J. Anim. Sci. 93:17801791.

Šebek, L. B. J., and H. Everts. 1999. In situ rumen degradation of dry matter and crude protein in ewes and dairy cows. Anim. Sci. 68:801-808.

Siddons, R. C., and J. Paradine. 1983. Protein degradation in the rumen of sheep and cattle. J. Sci. Food. Agric. 4:701-708.

Śliwiński, B. J., M. Kreuzer, H.-R. Wettstein, and A. Machmüller. 2002. Rumen fermentation and nitrogen balance of lambs fed diets containing plant extracts rich in tannins and saponins, and associated emissions of nitrogen and methane. Arch. Tierernahr. 56:379-392.

Soto-Navarro, S. A., R. Lopez, C. Sankey, B. M. Capitan, B. P. Holland, L. A. Balstad, and C. R. Krehbiel. 2014. Comparative digest- ibility by cattle versus sheep: Effect of forage quality. J. Anim. Sci. 92:1621-1629.

Staerfl, S. M., J. O. Zeitz, M. Kreuzer, and C. R. Soliva. 2012. Methane conversion rate of bulls fattened on grass or maize silage as compared with the IPCC default values, and the long-term methane mitigation efficiency of adding acacia tannin, garlic, maca and lupine. Agric. Ecosyst. Environ. 148:111-120.

Südekum, K.-H., H. Röh, M. Brandt, G. Rave, and M. Strangassinger. 1995. Comparative digestion in cattle and sheep fed wheat silage diets at low and high intakes. J. Dairy Sci. 78:1498-1511.

Swainson, N. M., S. O. Hoskin, H. Clark, C. S. Pinares-Patiño, and I. M. Brookes. 2008. Comparative methane emissions from cattle, red deer and sheep. Proc. N.Z. Soc. Anim. Prod. 68:59-62.

Tavendale, M. H., L. P. Meagher, D. Pacheco, N. Walker, G. T. Attwood, and S. Sivakumaran. 2005. Methane production from in vitro rumen incubations with Lotus pedunculatus and Medicago sativa, and effects of extractable condensed tannin fractions on methanogenesis. Anim. Feed Sci. Technol. 123-124:403-419.

Tiemann, T. T., C. E. Lascano, H. R. Wettstein, A. C. Mayer, M. Kreuzer, and H. D. Hess. 2008. Effect of the tropical tannin-rich shrub legumes Calliandra calothyrsus and Flemingia macrophylla on methane emission and nitrogen and energy balance in growing lambs. Animal 2:790-799.

Tomkins, N., A. J. Parker, G. Hepworth, and M. J. Callaghan. 2016. Nitrate supplementation has marginal effects on enteric methane production from Bos indicus steers fed Flinders grass (Iseilema spp.) hay, but elevates blood methaemoglobin concentrations. Anim. Prod. Sci. 58:262-270. https://doi.org/10.1071/AN16002.

Troy, S. M., C.-A. Duthie, J. J. Hyslop, R. Roehe, D. W. Ross, R. J. Wallace, A. Waterhouse, and J. A. Rooke. 2015. Effectiveness of nitrate addition and increased oil content as methane mitigation strategies for beef cattle fed two contrasting basal diets. J. Anim. Sci. 93:1815-1823.

Tyrrell, H. F., and P. W. Moe. 1972. Net energy value for lactation of a high and low concentrate ration containing corn silage. J. Dairy Sci. 55:1106-1112.

Udén, P., and P. J. Van Soest. 1984. Investigations of the in situ bag technique and a comparison of the fermentation in heifers, sheep, ponies and rabbits. J. Anim. Sci. 58:213-221.

Ulyatt, M. J., K. R. Lassey, I. D. Shelton, and C. F. Walker. 2002. Seasonal variation in methane emission from dairy cows and breeding ewes grazing ryegrass/white clover pasture in New Zealand. N. Z. J. Agric. Res. 45:217-226.

Ungerfeld, E. M., and R. A. Kohn. 2006. The role of thermodynamics in the control of ruminal fermentation. Pages 55-85 in Ruminant physiology: Digestion, metabolism and impact of nutrition on gene expression, immunology and stress. K. Sejrsen, T. Hvelplund, and M. O. Nielsen, ed. Wageningen Academic Publishers, Wageningen, the Netherlands.

Van Dorland, H. A., H.-R. Wettstein, H. Leuenberger, and M. Kreuzer. 2007. Effect of supplementation of fresh and ensiled clovers to ryegrass on nitrogen loss and methane emission of dairy cows. Livest. Sci. 111:57-69.

van Gastelen, S., E. C. Antunes-Fernandes, K. A. Hettinga, G. Klop, S. J. J. Alferink, W. H. Hendriks, and J. Dijkstra. 2015. Enteric methane production, rumen volatile fatty acid concentrations, and milk fatty acid composition in lactating Holstein- Friesian cows fed grass silage- or corn silage-based diets. J. Dairy Sci. 98:1915-1927.

Van Kessel, J. A. S., and J. B. Russell. 1996. The effect of pH on ruminal methanogenesis. FEMS Microbiol. Ecol. 20:205-210.

Van Klevenhusen, F., J. O. Zeits, S. Duval, M. Kreuzer, and C. R. Soliva. 2011a. Garlic oil and its principal component diallyl disulfide fail to mitigate methane, but improve digestibility in sheep. Anim. Feed Sci. Technol. 166-167:356-363.

Van Klevenhusen, F., J. O. Zeits, S. Duval, M. Kreuzer, and C. R. Soliva. 2011b. Diallyl disulphide and lovastatin: Effects on energy and protein utilisation in, as well as methane emission from, sheep. Arch. Anim. Nutr. 65:255-266.

van Lingen, H. J., C. M. Plugge, J. G. Fadel, E. Kebreab, A. Bannink, and J. Dijkstra. 2016. Thermodynamic driving force of hydrogen 
on rumen microbial metabolism: A theoretical investigation. PLoS One 11:e0161362.

van Zijderveld, S. M., J. Dijkstra, H. B. Perdok, J. R. Newbold, and W. J. J. Gerrits. 2011b. Dietary inclusion of diallyl disulfide, yucca powder, calcium fumarate, an extruded linseed product, or medium-chain fatty acids does not affect methane production in lactating dairy cows. J. Dairy Sci. 94:3094-3104.

van Zijderveld, S. M., W. J. J. Gerrits, J. A. Apajalahti, J. R. Newbold, J. Dijkstra, R. A. Leng, and H. B. Perdok. 2010. Nitrate and sulfate: Effective alternative hydrogen sinks for mitigation of ruminal methane production in sheep. J. Dairy Sci. 93:5856-5866.

van Zijderveld, S. M., W. J. J. Gerrits, J. Dijkstra, J. R. Newbold, R. B. A. Hulshof, and H. B. Perdok. 2011a. Persistency of methane mitigation by dietary nitrate supplementation in dairy cows. J. Dairy Sci. 94:4028-4038.

Velazco, J. I., D. J. Cottle, and R. S. Hegarty. 2014. Methane emissions and feeding behaviour of feedlot cattle supplemented with nitrate or urea. Anim. Prod. Sci. 54:1737-1740.

Veneman, J. B., S. Muetzel, K. J. Hart, C. L. Faulkner, J. M. Moorby, H. B. Perdok, and C. J. Newbold. 2015. Does dietary mitigation of enteric methane production affect rumen function and animal productivity in dairy cows? PLoS One 10:e0140282.

Vyas, D., S. M. McGinn, S. M. Duval, M. Kindermann, and K. A. Beauchemin. 2016. Effects of sustained reduction of enteric methane emissions with dietary supplementation of 3-nitrooxypropanol on growth performance of growing and finishing beef cattle. J. Anim. Sci. 94:2024-2034.

Vyas, D., S. M. McGinn, S. M. Duval, M. K. Kindermann, and K. A. Beauchemin. 2018. Optimal dose of 3-nitrooxypropanol for de- creasing enteric methane emissions from beef cattle fed high-forage and high-grain diets. Anim. Prod. Sci. 58:1049-1055.

Waldo, D. R., H. F. Tyrrell, A. V. Capuco, and C. E. Rexroad Jr. 1997. Components of growth in Holstein heifers fed either alfalfa or corn silage diets to produce two daily gains. J. Dairy Sci. 80:1674-1684.

Warner, D., A. Bannink, B. Hatew, H. van Laar, and J. Dijkstra 2017. Effects of grass silage quality and level of feed intake on enteric methane production in lactating dairy cows. J. Anim. Sci. 95:3687-3700.

Warner, D., B. Hatew, S. C. Podesta, G. Klop, S. van Gastelen, H. van Laar, J. Dijkstra, and A. Bannink. 2016. Effects of nitrogen fertilisation rate and maturity of grass silage on methane emission by lactating dairy cows. Animal 10:34-43.

Warner, D., S. C. Podesta, B. Hatew, G. Klop, H. van Laar, A. Bannink, and J. Dijkstra. 2015. Effect of nitrogen fertilization rate and regrowth interval of grass herbage on methane emission of zerograzing lactating dairy cows. J. Dairy Sci. 98:3383-3393.

Waugh, C. D., D. A. Clark, G. C. Waghorn, and S. L. Woodward. 2005. Feeding maize silage to dairy cows: Implications for methane emissions. Proc. N.Z. Soc. Anim. Prod. 65:356-361.

Woodward, S. L., G. C. Waghorn, and P. G. Laboyrie. 2004. Condensed tannins in birdsfoot trefoil (Lotus corniculatus) reduce methane emissions from dairy cows. Proc. N.Z. Soc. Anim. Prod. 64:160-164.

Woodward, S. L., G. C. Waghorn, M. J. Ulyatt, and K. R. Lassey. 2001. Early indications that feeding Lotus will reduce methane emissions from ruminants. Proc. N.Z. Soc. Anim. Prod. 61:23-26. 